\title{
Management of Knowledge, Innovation and Performance in SMEs
}

\author{
Luis Enrique Valdez-Juárez \\ Instituto Tecnológico de Sonora, Ciudad Obregón, México \\ levaldez@itson.edu.mx \\ Domingo García-Pérez de Lema \\ Polytechnic University of Cartagena (UPCT), Cartagena, Spain \\ domingo.garcia@upct.es
}

\author{
Gonzalo Maldonado-Guzmán \\ SME Observatory at the Autonomous University of \\ Aguascalientes, Aguascalientes, Mexico \\ gmaldona@correo.uaa.mx
}

\begin{abstract}
For more than two decades, knowledge management (KM) has been examined in the literature and considered a basic factor in business management. The purpose of this article is to explore the ability of knowledge management to achieve small and medium-sized enterprise (SME) innovation and business performance. Data analysis procedures of PLS-SEM was used to analyze the data based on responses from the owners of 903 companies in industry, construction, services, and trade in the Region of Murcia (Spain) through a self-directed survey. The results show that KM has a significant influence on innovation but the influence on the level of performance of SMEs is insignificant. However, training employees as part of KM showed no significant influence on innovation in SMEs. It is important for leaders and managers to have greater openness to changes in the implementation and proper execution of KM. This work contributes primarily to the development of the literature on knowledge management and its relationship with innovation and business performance.
\end{abstract}

Keywords: Knowledge management (KM), innovation, performance, small and medium-sized enterprises (SMEs), information and communication technology (ICT).

Material published as part of this publication, either on-line or in print, is copyrighted by the Informing Science Institute. Permission to make digital or paper copy of part or all of these works for personal or classroom use is granted without fee provided that the copies are not made or distributed for profit or commercial advantage AND that copies 1) bear this notice in full and 2) give the full citation on the first page. It is permissible to abstract these works so long as credit is given. To copy in all other cases or to republish or to post on a server or to redistribute to lists requires specific permission and payment of a fee. Contact Publisher@,InformingScience.org to request redistribution permission.

\section{Introduction}

The era of knowledge plays an essential role in the economic growth and development of all enterprises (Foray, 2004; Mosconi \& Roy, 2013). With the arrival of globalization, knowledge has become an intangible resource generator of permanent competitive advantage (Ikujiro \& Hiroshi, 2013; Tunc Bozbura, 2007) 
and contributes to the generation of intellectual capital and to the economic activities of organizations (Kristandl \& Bontis, 2007). In these times of constant motion, small and medium-sized enterprises (SMEs) require the extraction of knowledge from both domestic sources and foreign sources to achieve greater participation in the markets, foster innovation, and improve performance (Gold, Malhotra, \& Segars, 2001; Morgan \& Berthon, 2008). Knowledge management $(\mathrm{KM})$ is a comprehensive approach that includes capture, receipt, and transfer of information in a company that considers the policies, procedures, knowledge, and experience of employees (Duhon, 1998). In addition, technology systems influence the behavior of employees and strengthen a culture based on the use and transfer of information (Davenport, 1994). KM is a business practice that integrates essential strategies, policies, techniques, and procedures (Davenport, 2013; Lavergne \& Earl, 2006). The alignment of corporate strategy with KM is vital for adding value and achieving results (Chuang, 2004; M. H. Zack \& Singh, 2010). KM influences business systems by increasing profitability, creating a harmonious atmosphere among employees, and ensuring businesses' sustainability and competitiveness (Darvish, Mohammadi, \& Afsharpour, 2012; Darvish \& Nazari, 2013). However, KM is not sufficiently widespread in SMEs, mainly due to the lack of strategic planning, lack of financial resources, distaste to change cultural, uncertainty regarding benefits, and technological immaturity, which are typical in these organizations (Edvardsson \& Durst, 2013; Yew Wong, 2005).

A reasonable number of empirical studies have analyzed the impact of KM and innovation in SMEs (Constantinescu, 2009; C. Yu, Yu-Fang, \& Yu-Cheh, 2013). However, the relationship between innovation and performance is still a wide field for exploration (Price, Stoica, \& Boncella, 2013; Vaccaro, Parente, \& Veloso, 2010). Works on KM have placed minimal emphasis on the benefits generated in SMEs; the majority of research focuses on large organizations (Darroch, 2005; Roxas, Battisti, \& Deakins, 2014). In addition, minimal understanding of how companies create, transfer, and use knowledge has led to difficulty in transforming knowledge into a competitive advantage (C. Lin, Wu, \& Yen, 2012; Perrin, Vidal, \& McGill, 2006). The difficulty of measuring KM in SMEs provides a reasonable explanation for the scarcity of empirical studies in this developing discipline (Becerra-Fernandez \& Sabherwal, 2014; Choi, Poon, \& Davis, 2008). By the great influence of the KM in the progress and development of SMEs, it is important to develop this type of study more regularly (Imran, 2014; Vaccaro et al., 2010).

The objective of this work is to empirically analyze the relationships between KM, innovation, and performance in SMEs in the region of Murcia, Spain. In the current competitive global environment, it is important to analyze the key factors that affect the development and growth of these companies. The research questions that we attempt to answer are as follows:

1. Does knowledge management influence innovation activities in SMEs?

2. Does business innovation exert any influence on SME performance?

Literature reveals that KM can help SMEs to professionally develop employees, improve innovation processes, grow sales, satisfy customers and thus achieve organizational success (Edvardsson \& Durst, 2013; López-Nicolás \& Meroño-Cerdán, 2011; Madrid-Guijarro, Garcia, \& Van Auken, 2009). This paper contributes to the literature on KM in two ways. First, we analyze the KM in the area of SMEs and consider their relationship with innovation and performance. This aspect indicates areas of opportunity for SMEs to undertake actions for improvement that contribute to the development of human capital and competitiveness. Secondly, we analyze the innovation processes in the organization and their possible mediating role for achieving development and increased profitability in SMEs.

This paper is organized in the following manner. The first part presents the structure of the theoretical framework, a review of empirical studies published in the literature, and the hypotheses to test. The second part explains the methodology, the sample, and the justification of the variable 
used. The third section presents the results of the hypothesis. Finally, the discussion and the conclusions of the study are presented.

\section{Literature and Hypothesis Development}

$\mathrm{KM}$ has its origins in a conceptual perspective based on theories developed by W. M. Cohen and Levinthal (1990) that involve the absorptive capacity of employees to be more innovative. KM focuses on extracting knowledge from technology, competitors, and investment in R\&D that generate productivity in an organization (Caragliu \& Nijkamp, 2012). Knowledge is extracted from both inside and outside the company using a spiral model suggested by Nonaka and Takeuchi (1995). This model involves the members of all lines of the organization and allows them to gain competitive advantage (Chen, Lin, \& Chang, 2009; Porter, 2011; M. Zack, McKeen, \& Singh, 2009). Other theories solely consider explicit knowledge as the means to generate innovation and productivity in an organization (Hansen, Nohria, \& Tierney, 2005). Conversely, there are approaches that focus on tacit knowledge for the achievement of organizational objectives (Scarbrough \& Swan, 2001). KM is a systematic process to acquire, share, and use productive knowledge in the process of improving the performance of organizations (Augier \& Teece, 2009; Swan, Newell, Scarbrough, \& Hislop, 1999). KM is of utmost importance for the value of the business (Anand, Kant, Patel, \& Singh, 2012; Battistella, De Toni, \& Pillon, 2015). KM encourages the transfer of information for the purpose of enhancing the capabilities of employees and strengthening the organizational culture (Amidon, Formica, Mercier-Laurent, \& Ülikool, 2005; Davenport, Thomas, \& Cantrell, 2012). This corporate strategy is an effective way to encourage innovation and to increase competitiveness and profitability in companies of different sizes (Abdolvahabi, Sofiyabadi, Abdolvahabi, \& Valmohammadi, 2014; Bagnoli \& Vedovato, 2014; Palacios-Marqués, Soriano, \& Huarng, 2015). Since its inception, KM has been adopted mainly by large corporations (J. F. Cohen \& Olsen, 2015; Delen, Zaim, Kuzey, \& Zaim, 2013). Despite being an effective tool that generates competitive advantage in business, it is a business practice that remains in development (Bagnoli \& Vedovato, 2014; Wiig, 2002). Companies on their way to learning have experienced different phases and models to improve their KM processes (AlHakim, 2013; Nonaka, Kodama, Hirose, \& Kohlbacher, 2014).

The literature presents a wide variety of models to measure KM in organizations (Cannella \& McFadyen, 2013; Kaplan, Norton, \& Rugelsjoen, 2010; Nonaka et al., 2014). The most recognized in the literature are the individual-oriented (Bontis, 2001; Nonaka \& Takeuchi, 1995; Roos \& Roos, 1997), the technology-oriented (Chang \& Lee, 2008; Swan, Scarbrough, \& Robertson, 2002; Tanriverdi, 2005), and the business process-centric models (Bontis, Wu, Wang, \& Chang, 2005; Davenport et al., 2012; Peinl \& Maier, 2011). These models have been used as references to determine the content of the variables that shape our research model, which is proposed to measure knowledge management in SMEs. The model focuses on the individuals and contributes to the structure of the dimension related to the formation and training of human capital. The training of employees is a business practice that increases intellectual capital and generates greater value for the organization (OECD, 2003; Shih, Chang, \& Lin, 2010; Youndt, Subramaniam, \& Snell, 2004). Previous models provide the basis of our model with regard to the definition and importance of the use of ICT for organizations for the acquisition of knowledge, the storage of the information, the culture to share it, and the ability to codify the knowledge. The knowledge acquired in an organization should flow and have a positive impact on the achievement of corporate objectives based on the implementation of excellent strategies and clear definitions of policies in knowledge management (M. B. Jensen, Johnson, Lorenz, \& Lundvall, 2007; Yang, 2010). The capture and acquisition of a company's knowledge are crucial to increase the capacities of staff (Pai \& Chang, 2013; Von Krogh, Takeuchi, Kase, \& González, 2013). Models that focus on these processes support our model in the composition of issues related to the variables, including organizational culture and the politics of knowledge management. In a KM process, the effect of 
organizational culture is composed of the philosophy, values, and principles of the company from the director to the staff at lower hierarchical levels. Although these models have primarily been adopted and executed by large corporations, it is important to adapt them to the context of SMEs to analyze their impact (Delen et al., 2013), see Figure 1.

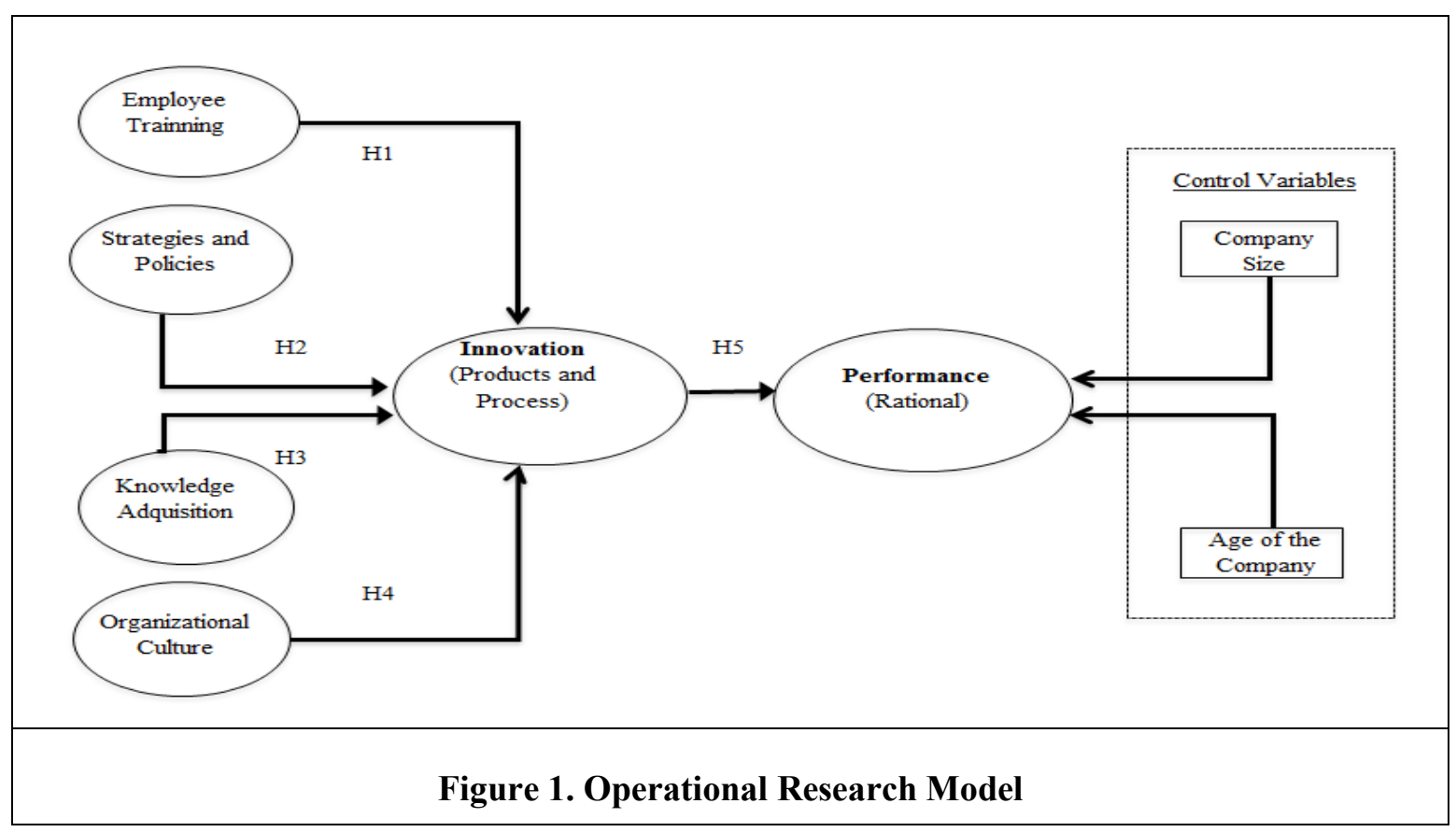

KM promotes the survival of a company by boosting activities aimed at innovation (Drucker, 1999; Mudambi, 2008; Renzl, 2008). Innovation is related to the knowledge, performance, and capabilities of the company (Palacios Marqués \& José Garrigós Simón, 2006). Thus, KM becomes part of the strategic construction of a company and provides indirect support for innovative results (Darroch \& McNaughton, 2002). KM can help SMEs obtain more skilled human capital and better talent (Burcharth, Knudsen, \& Søndergaard, 2014; Gallié \& Legros, 2012), as well as greater acquisition of internal and external knowledge supported by new information technologies (Huang, Wang, Gardoni, \& Amadou, 2014; Martin \& Matlay, 2003). Recently, KM has been used to generate innovation and performance through the clustering of SMEs (Lai, Hsu, Lin, Chen, \& Lin, 2014; Moffett \& Hinds, 2010).

\section{The Training of Employees and the Influence on Innovation}

Training is a basic factor in the contribution of KM to organizations, and it is even more so with regard to SMEs (Moffett \& Hinds, 2010). Therefore, companies must offer training opportunities to develop and nurture knowledge and to share employees' experiences (Nonaka et al., 2014). Training is understood as objective evidence of practical activities that enable the acquisition of skills for work related to the reason for the existence of an SME (Holsapple, 2013; Ragab \& Arisha, 2013; Remus, 2012). KM can influence the capabilities of employees through training, motivation, and compensation to achieve objectives and to develop new knowledge in an organization (Bozbura, Beskese, \& Kahraman, 2007; Garavan, O'Brien, \& Murphy, 2014). Within a system of KM, employee training plays an important role in the achievement of organizational goals (Asif, de Vries, \& Ahmad, 2013; Becerra-Fernandez \& Sabherwal, 2014). Human resources can acquire knowledge inside and outside the company through other employees and training (Asif et al., 2013; Manuti, Pastore, Scardigno, Giancaspro, \& Morciano, 2015). The absorption capacity, such as training, is fundamental to employee training not only with regard to conceptual 
skills but also in the development of technical skills (Carrillo, Schiuma, \& Lerro, 2008; Gray, 2006). The education and training of employees are related to innovation in terms of the company's investment in R\&D and the training plans developed (Burcharth et al., 2014; Gallié \& Legros, 2012; Schmitt, 2015). Companies that do not invest in training programs will have few favorable results (De Saá-Pérez, Díaz-Díaz, \& Luis Ballesteros-Rodriguez, 2012).

Formal training contributes to the generation of knowledge by encouraging an increase in intellectual capital and transferring it to employees with talent, by utilizing compensation systems that are conducive to driving innovation (Fullan, 2014; Tunc Bozbura, 2007). Managers of small businesses with a high level of education and training focus primarily on the innovation of their products, whereas managers of medium-sized enterprises' innovation efforts focus both on products and services and on processes (Chen \& Huang, 2012; Martínez-Ros \& Orfila-Sintes, 2012). Training plays a moderating role and has a significant influence on the knowledge and skills necessary to encourage an increased intensity of innovation, productivity, competitive advantage, and performance in SMEs (Gallié \& Legros, 2012; Nonaka et al., 2014). Based on the foregoing, the following hypothesis arises:

H1. A higher level of training for employees in SMEs contributes positively to the level of innovation.

\section{Strategy and Innovation Policies}

Organizations should focus on generating strategies and policies that ensure a competitive advantage (Porter, 2011; D. Quinn \& Shapiro, 1991). A strategy is defined as a pattern or plan that integrates goals, policies, and sequential actions that lead to a cohesive organizational plan (Mintzberg, 2011; Minzberg \& Quinn, 1991; J. Quinn, 2005). Given that policies are part of a strategy, policies are defined as action guides containing rules and responsibilities for each area of an organization's work (Blumentritt \& Danis, 2006; Michie \& Sheehan, 2005). Policies and strategies within a system of KM refer to rules, conditions for the use of the information, and the protection of intellectual property (Prusak \& Matson, 2006; Wiig, 2002). These practices are part of a differentiation strategy that generates competitive advantage for enterprises (Boyes, 2011; Sople, 2014; Yüksel, 2008). Through the establishment of strategies and policies for the use of knowledge, KM has been identified as an important element to generate creativity and boost innovation (Darroch \& McNaughton, 2002; Rahimi, Arbabisarjou, Allameh, \& Aghababaei, 2011). Studies of SMEs in different countries reveal that the adoption of strategies, practical human resources (development, the promotion of employees and staff retention incentives), and knowledge management policies contribute to the productivity of the company and have a positive impact on innovation (Constantinescu, 2009; Durst, Edvardsson, \& Bruns, 2013).

Some strategies are based on human resources (customization, coding, and collaboration), whereas others are based on the information of technology (the use of information and data protection). These strategies have positively impacted innovation tasks in SMEs (Vaccaro et al., 2010). When there is a combination of both strategies of $\mathrm{KM}$, there is a tendency toward a greater impact on innovation (Gloet \& Terziovski, 2004; Hansen et al., 2005). Other studies emphasize the fundamental role of KM by adopting strict internal policies that strongly support creativity at work and encourage innovation (Alegre, Sengupta, \& Lapiedra, 2013; Černe, Nerstad, Dysvik, \& Škerlavaj, 2014; McAdam, Reid, \& Gibson, 2004). Policies that are based on the protection of knowledge encourage organizations to have greater control of information and knowledge and have a significant relationship to the creativity and performance of the company (Berce, Lanfranco, \& Vehovar, 2008). The implementation of strategies and policies as a means to manage knowledge leads to an increased intensity of R\&D on products and processes and generates a higher yield in the business (Cantner, Joel, \& Schmidt, 2011; López-Nicolás \& Meroño-Cerdán, 2011; Lopez- 
Management of Knowledge, Innovation and Performance in SMEs

Nicolas \& Soto-Acosta, 2010). Based on the review of the literature and previous studies, this approach is considered as follows:

H2. With a higher level of knowledge management policies and strategies, there is a higher level of innovation in SMEs.

\section{The Acquisition of Knowledge and its Relationship with Innovation}

The acquisition of knowledge is defined as the process of exploiting and extracting ideas, thoughts, and creations by individuals to help transform a company into a dynamic organization (Von Krogh et al., 2013; Zahra \& George, 2002). Knowledge is available through various sources that may be internal or external. Employees subsequently transform these sources into new knowledge (Simatupang \& White, 2010; Y. Yu, Dong, Shen, Khalifa, \& Hao, 2013). Knowledge "based on the experience learned implicitly and internalized by individuals is known as tacit knowledge, and that which you learn in a rational manner and exteriorized form is known as explicit knowledge" (Nonaka, 2008). SMEs seek harmony between the realization of R\&D internal and external learning. This is one of the most elementary aspects of the management of innovation (Aming'a, 2015; Arora, Belenzon, \& Rios, 2014; Leiponen \& Helfat, 2010). From a strategic perspective, the internal resources of a company play a double role in innovation because they determine the possibility of use and external knowledge (W. M. Cohen, 2010; W. M. Cohen \& Levinthal, 1990). In the last two decades, studies of innovation in combination with the acquisition of knowledge indicate that there is systematic and fundamental change in the manner in which businesses conduct innovative activities (Norman \& Verganti, 2014; Zahra \& George, 2002; Zeng, Xie, \& Tam, 2010). Rapid changes in the environment and the specialization required by technological advancements are pushing companies to use primarily external knowledge (Zhu, Wittmann, \& Peng, 2011).

Results from various studies conclude that a company that is able to effectively develop the acquisition of knowledge and consider it a crucial task can achieve organizational benefits both in innovation and in operating results (Darroch, 2005; Nawaz, Hassan, \& Shaukat, 2014; Rahimi et al., 2011). Explicit knowledge is currently collected in enterprises through information technologies such as databases, web sites, e-reports, presentations, and social networks that are inside and outside the organization and that support substantial changes to methodologies and processes (Asare, Gopolang, \& Mogotlhwane, 2012; Chen \& Huang, 2012). Tacit knowledge based on the experience of employees, customers, and suppliers is an important element for companies given the intellectual value that it represents, which helps to generate innovative ideas (Andrés, Asongu, \& Amavilah, 2014; Nonaka et al., 2014). The acquisition of knowledge has become a decisive factor for the improvement of employee training and leads to the strengthening of best practices in innovation in a company (Durst \& Edvardsson, 2012; Pai \& Chang, 2013). The acquisition of knowledge has significant results that lead to competitive advantage, increased sales, new product development, adaptations, and improvements in innovation processes (Kale \& Karaman, 2012; Nawaz et al., 2014; Sain \& Wilde, 2014). Based on the previous analysis, the following hypothesis arises:

H3. A higher level of knowledge acquisition in SMEs has a positive influence on a higher level of innovation.

\section{Organizational Culture and the Relationship with Innovation}

Organizational culture is a strategic business practice in which the principles and values of an organization emerge (Robbins, DeCenzo, \& Gao, 2007; Zheng, Yang, \& McLean, 2010). Culture is defined as a pattern of basic assumptions that a group has created, discovered, or developed by 
learning to cope with problems and teaching new members the means by which to solve the problems correctly (Schein, 1990, 2010; Shafritz, Ott, \& Jang, 2015). It is also considered the pool of knowledge that differentiates employees in an organization (Cavaliere \& Lombardi, 2015; Hofstede, Hofstede, \& Minkov, 2010). The organizational process of KM culture is one of the best corporate strategies for the transfer of information and is a factor in success or failure (Bartol \& Srivastava, 2002; W.-B. Lin, 2008; S. Wang \& Noe, 2010). When employees have a culture of sharing and transfer valuable information in the enterprise, corporate objectives are accomplished (Foss, Husted, \& Michailova, 2010; Michailova, McCarthy, Puffer, May, \& Stewart Jr, 2013). In addition, when the culture of information sharing is promoted and encouraged, prominent competitive advantage can be achieved (Abdul-Jalal, Toulson, \& Tweed, 2013; Jelavic, 2011; Parjanen, 2012).

There are strategies to improve and promote innovation through the culture in an organization. For example, Chen and Jaw (2009) and Linderman, Schroeder, and Sanders (2010) suggest that outwardly businesses usually have a wide variety of mechanisms to increase their chances of obtaining information regarding their business environment and promoting innovation activities. The main findings of various studies show that organizational culture involves the commitment, system of values, knowledge of corporate philosophy, and professional ethics of employees that contribute to the daily activities of SMEs to improve innovation through creativity and the development of new products (Syed \& Lin, 2013; Tseng \& Fan, 2011). Values and professional ethics increasingly play an essential role in enterprises to generate the number of clients and improve the relationship between suppliers and co-workers. This is due to trust and collaboration, which aim to meet both the expectations and commitments generated (Senaji \& Nyaboga, 2011; Yew Wong, 2005). These actions contribute to the generation of adaptations in working procedures and methods. Organizational culture can affect the innovation of the enterprise, both positively and negatively (Naranjo-Valencia, Jiménez-Jiménez, \& Sanz-Valle, 2011). The adhocracy culture fosters innovation orientation, whereas the culture of hierarchy is associated with imitation, limiting employees' creativity and the ability to innovate (O'Regan, Ghobadian, \& Sims, 2006; Škerlavaj, Song, \& Lee, 2010). A small company must focus on the harmony of a corporate philosophy based on values that allow employees to commit to the proper use of information in database systems for customers, suppliers, and staff. These practices contribute significantly to the improvement of innovation processes (Dixit \& Nanda, 2011; Maheshwarkar \& Sohani, 2013). Based on these results, we present the following hypothesis:

H4. A higher level of organizational culture creates a higher level of innovation in SMEs.

\section{The Management of Knowledge, Innovation and Business Performance}

Schools of theories, such as that of W. M. Cohen and Levinthal (1990), have contributed to the study of the management of knowledge and the manner in which it is acquired to generate ideas and new products and to improve productivity in an organization (Robertson \& Jacobson, 2011; Zahra \& George, 2002). KM, through dynamic capabilities, serves to explain the success or failure, the generation of financial performance, competitive advantage, and innovation over time of an organization (Augier \& Teece, 2009; Zahra \& Hayton, 2008). The companies that stand out in terms of innovation and operational performance have adopted the strategy of organizational culture emphasizing cooperation and exchange of knowledge because they have recognized the value of KM for competitiveness (Kamyabi \& Devi, 2012; Ragab \& Arisha, 2013). KM is a key factor in generating innovation, and it serves as a facilitator to achieve performance (R. Harris, McAdam, McCausland, \& Reid, 2013; Kostopoulos, Papalexandris, Papachroni, \& Ioannou, 2011). Often, organizations invest in the implementation of business strategies through the acquisition, transfer, and use of knowledge. Organizations are likely to achieve substantial improve- 
ments in innovation and better performance, which can lead to greater productivity (Bagnoli \& Vedovato, 2014; Roxas et al., 2014). In addition, some studies indicate that the few SMEs that incorporate KM into their human resources practices tend to be more innovative and to achieve economic results more easily (Price et al., 2013; Vaccaro et al., 2010).

There is also evidence from studies on SMEs in the technology sector that the management of knowledge supported by IT facilitates the generation of innovation and, in turn, increases both the productivity and profitability of organizations (Chen \& Huang, 2012; Schiuma, Andreeva, \& Kianto, 2012). Recent research on SMEs in the industrial sector (manufacturing) shows that KM is significantly related to innovation, allowing the generation of new products and improvements in production processes and impacting operational and financial performance (Jayasingam, Ansari, Ramayah, \& Jantan, 2013; Noruzy, Dalfard, Azhdari, Nazari-Shirkouhi, \& Rezazadeh, 2013). After analyzing the relationship between the variables in this study, the following hypothesis is presented:

H5. A higher level of innovation leads to a higher level of business performance.

\section{Methodology}

The data in our study were obtained through personal interviews with 903 managers of the Spanish SMEs. The interviews were conducted by the "SME Economic Observatory", a research center for SMEs funded by the Instituto de Fomento of the Region of Murcia. The finite populations stratified sampling principle was adopted in the sample design. The populations of the companies were segmented according to the type of business each company is in. Those companies are classified into four sectors: Industry, Construction, Trade, and Services. The companies in each sector were identified using information from the Central Directory of Companies of the INE (INE, 2010). Companies with fewer than five workers were not included in the sample. The sample size was determined to ensure that the margin of error for the estimate of a proportion (relative frequency response in a specific item of question) would be less than 0.03 points with a $95 \%$ confidence level. The general characteristics of the sample are shown in Table 1 . We can see that $46.3 \%$ of the sample belongs to the industrial sector, $20.6 \%$ to the sector of construction, $16.9 \%$ to service, and companies in the trade sector, $16.2 \%$. The average size of the companies in the sample was 29 employees, and the average age of the companies was 21 years. The channel for collecting information was personal interviews with support from a self-administered questionnaire directed to the manager of the company. Control tests were part the elaboration process of the survey. Fieldwork was conducted during April to July 2010. Companies that refused to participate in the project were replaced by a similar company (chosen randomly) of the same business and geographical area. The bias of response was not analyzed (Nwachukwu, Vitell, Gilbert, \& Barnes, 1997). The responses of the companies that responded in the first round of interviews ( $80 \%$ of the sample) were compared with those that responded by replacement $(20 \%$ of the sample). No significant differences between the two groups emerged from the variables considered, using $\mathrm{t}$ tests and chi-square tests. In addition, common method variance (CMV) bias was analyzed, since the data came from a single source of information through a single questionnaire. It is possible that the relationships between the variables were inflated as a consequence of CMV. To identify the existence of such bias, we used Harman's single-factor test, as suggested by Podsakoff and Organ (1986) and Reio (2010). The variance explained by the factors in our study is over $69 \%$. The six theory constructs in the model are clearly identified in factor analysis (KMO: 0.893; Bartlett sphericity test 0,000.). These results all suggest that the common method bias was not a big concern in our study. 
Table 1. Sample characteristics

\begin{tabular}{|l|l|l|}
\hline \multicolumn{1}{|c|}{ Sectors of activity } & \multicolumn{1}{|c|}{ Number of Firms } & \multicolumn{1}{c|}{ Percent of Total } \\
\hline Industry & 418 & 46.3 \\
\hline Construction & 186 & 20.6 \\
\hline Services & 153 & 16.9 \\
\hline Trade & 146 & 16.2 \\
\hline Total & 903 & 100.0 \\
\hline
\end{tabular}

\section{Measurement of the Variable}

One most critical criterion to correctly analyze the variables of the model is to understand the nature and direction of causality between the constructs (Esposito Vinzi, Chin, Henseler, \& Wang, 2010). This type of analysis determines the statistic to use and allows us to understand and assess more accurately the measurement model and the structural model technique (Henseler, Ringle, \& Sarstedt, 2015; Peng \& Lai, 2012). According to the design and the characteristics of the questions in the questionnaire, the research was developed with variables of the reflective type (see the Appendix).

Reflective variables were used in the study. The main feature of these models is that the direction of influence ranges from the construct toward indicators. The indicators and/or observed variables constitute a reflection or expression of the construct that is not observed but that is linked (Bollen \& Lennox, 1991; Jarvis, MacKenzie, \& Podsakoff, 2003). Reflective variables are characterized by all indicators of a construct being highly correlated (co-variant); they are interchangeable, and the theoretical significance of the construct having similar content is not altered to remove any indicator (Jarvis et al., 2003; Wetzels, Odekerken-Schröder, \& Van Oppen, 2009).

Knowledge Management. There are different proxies, both quantitative and qualitative, in the literature to measure this variable. Nonaka and Takeuchi (1995) and Davenport and Prusak (1998) have developed theories and models that are based on the measurement of knowledge that is acquired inside and outside the organization (socialization, externalization, combination, and internalization) using human resource practices such as introspection, social aptitude, motivation, social recognition and development, flexibility, and the use of technology to acquire and share knowledge. Managers of SMEs were asked to respond to the following questions that emerged from the variables (see Appendix); these were measured on a 5-point Likert-type scale $1=($ Extremely disagree), $5=$ (Extremely Agree). (1) Employee training was measured with 4 items and adapted from the study by Bontis, Bart, Nazari, and Herremans (2007), the OECD (2003), and Darroch (2005). (2) Policies and strategies for the management of knowledge were measured with 7 items and were adapted from the study by Bozbura et al. (2007) and López-Nicolás and Meroño-Cerdán (2011). (3) Creation and acquisition of external knowledge was measured with 5 items and adapted from the studies by Gold et al. (2001) and Bozbura et al. (2007). (4) Effects of organizational culture was measured with 4 four items and was adapted from the OECD (2003) and Tunc Bozbura (2004).

Innovation. Subjective measures of variables based on self-reports and reports based on the subjective value judgments of the owner and/or the manager are appropriate for SMEs because the objective measures tend to underestimate the degree of innovation (A. Hughes, 2001; B. Hughes \& Wareham, 2010). However, several studies have stated that measured perceptions are highly correlated with objective measures of innovation and have the advantage of facilitating comparisons between companies in different industries (Horte et al., 2008; Parida, Westerberg, \& Frishammar, 2012; Zahra, Ireland, \& Hitt, 2000). Based on the models of Ruggles and Little 
(1997), Nonaka and Nishiguchi (2001) and Šajeva and Jucevičius (2008), our questionnaire collects responses from managers to indicate whether the business introduced innovation during the previous two years $(1=$ yes, $0=$ no $)$ and also to indicate the degree of importance of the following innovation activities in their company: 1) Innovation in products and services: changes in products, the marketing of new products, 2) Innovation in processes: changes in manufacturing processes, and the acquisition of new equipment. A 5-point Likert-type scale was used to measure the importance of innovative activity, $1=$ (Unimportant), $5=$ (very important). Questions can be seen in the Appendix.

Performance. A subjective measure of performance was developed because, as noted by several authors, accounting information implies certain problems. The accounting information omitted certain intangible assets that are important to measure competitive success (B. S. Anderson \& Eshima, 2013; Kaplan et al., 2010). Measures of objective performance, such as return on assets, sales, and return on capital performance, had inherent problems due to the short-term approach; these are not risk adjusted and are difficult to relate to a specific innovation (Dekimpe \& Hanssens, 2004; Geyskens, Gielens, \& Gijsbrechts, 2010). Accounting measures are also based on historical costs and, therefore, may not accurately reflect the future (Kalyanaram, Robinson, \& Urban, 1995; Poletti, Engelland, \& Ling, 2011). In previous studies that analyzed performance linked to knowledge management, variables such as economic performance (J. Barney, 1991; J. B. Barney, 2001; Tanriverdi, 2006), market share (Chen \& Huang, 2012; Ebrahimi \& Sadeghi, 2013), and productivity (Hislop, 2013; Van Hemert, Nijkamp, \& Masurel, 2013) were considered. In this study, the managers answered questions to classify SMEs based on competitive positions in three areas (market share, profitability, and productivity) on a 5-point Likert scale. The details are contained in the Appendix.

\section{Control variables}

Company size. This variable was measured with the natural logarithm of the number of employees in 2009. The age of the company was measured with the number of years since the constitution or start-up of operations of the company. (See Table 2)

Traditionally, researchers have added these control variables to their models to analyze the influence they generate in organizations (Bagnoli \& Vedovato, 2014; Benitez-Amado \& Walczuch, 2012). The size of the company has frequently been related to organizational growth and economic and financial performance (C. Jensen \& Peng, 2013; Sigler, 2011). There are economic models to measure the size of a company (Winter, 2005). The dynamic capabilities of companies determine the magnitude of an organization through total assets, total employees, and total revenues (Augier \& Teece, 2009; Eisenberg, Sundgren, \& Wells, 1998; Schaper, Dana, Anderson, \& Moroz, 2009), which are also key to improved performance (Teece, 2007; Y. Wang, Chen, \& Benitez-Amado, 2015). The age of the company determines the degree of consolidation and maturity within a market, which is explained through evolutionary theory (Coad \& Hölzl, 2012; Nelson \& Winter, 2002; Winter, 2005). The economic and organizational growth of a company is based on the age of the organization (Bleda, Morrison, \& Rigby, 2013). These two variables are recurrent in different disciplines and are related to determining value, growth and the competitiveness of an organization (J. B. Barney, 2001; Friedman, 2006).

Table 2. Control variables

\begin{tabular}{|l|l|l|l|l|}
\hline & Minimum & Maximum & Media & Standard deviation \\
\hline Antiquity of the company (years) & 2 & 150 & 21,246 & 16,7983 \\
\hline Size of the company (number of employees) & 6 & 1007 & 29.85 & 71,833 \\
\hline
\end{tabular}




\section{Reliability and Validity}

The reliability and validity of the instrument used was determined through a structural equation model (SEM) to avoid measurement errors and multicollinearity (Hair, Black, Babin, Anderson, $\&$ Tatham, 2010). The SEM based on variance and/or covariance is a statistic with high precision that is frequently used by researchers in the areas of social and administrative sciences (Rigdon, 2012; J. Wang \& Wang, 2012). Our study analyzes the variables of the theoretical model through SEM based on variance, which provides the best fit to our research objectives. The main reasons for this second-generation technique are that it allows us to do the following: 1. estimate the measurement error; 2. estimate the relationships between different constructs (observable and unobservable); and 3. explore or confirm simple and complex theoretical models (Esposito Vinzi et al., 2010; Y. Wang et al., 2015). The partial least squares (PLS) method was used to address the relationships between research variables with a focus on variance-based SEM (Barclay, Higgins, \& Thompson, 1995; Hair, Hult, Ringle, \& Sarstedt, 2013). PLS-SEM is a technique that is used in research in different disciplines for its consistency and accuracy (Sarstedt, Ringle, Henseler, \& Hair, 2014). This method is based on the prediction of the empirical findings and contrasts them with the theory (Bagozzi \& Yi, 2012). The use of the PLS methodology involves a two-phased approach (Barclay et al., 1995; Ringle, Sarstedt, \& Straub, 2012): the measurement model and the structural model. The measurements are based on confirmatory factor analysis (CFA) to rule out the indicators that have a low correlation with respect to the remainder of the scale. In addition, the internal consistency and convergent and discriminant validity are analyzed (Fornell \& Larcker, 1981).

\section{Empirical Findings}

\section{Measurement Model}

To evaluate the measurement model with the reflective variables, the individual reliability of the item, the internal consistency or reliability of a scale, and convergent validity are discussed. The reliability of each individual item of standardized load-related factors is recommended to exceed .70, (Carmines \& Zeller, 1991; Chin \& Dibbern, 2010; Roberts, Priest, \& Traynor, 2006). The factor loadings as shown in Table 3 range from .662 to .928 , near or above .70, as proposed by Falk and Miller (1992) and Chin and Dibbern (2010). In our model, we have decided to include items with loading values of .662, 663, and .698 for the following reasons: 1 . they are significant at a level of $.001 ; 2$. they are very close to the permissible threshold of .70; 3 . these items are important to maintain the validity of construct (Y. Wang et al., 2015). The composite reliability shows stronger values in a range of .849-.925, meeting the requirement that indicator should be above .80 for basic research, as proposed by Nunnally (1978) and Vandenberg and Lance (2000). Cronbach's alpha is considered satisfactory over .70 (Hair, Black, Babin, Anderson, \& Tatham, 2006). Our results show values between .781-.892, which indicates high construct reliability. The average variance extracted (AVE) indicates the average amount of variance explained by the indicators of a construct. Our values for AVE range from 0.53 to 0.77 . These results are above the threshold of 0.5, as proposed by J. F. Hair et al. (2010). 
Table 3: Internal consistency and convergent validity of the theoretical model

\begin{tabular}{|c|c|c|c|c|}
\hline Construct & $\begin{array}{c}\text { Load } \\
\text { Factor }\end{array}$ & $\begin{array}{l}\text { Composite } \\
\text { Reliability }\end{array}$ & $\begin{array}{c}\text { Cronbach's } \\
\text { Alpha }\end{array}$ & AVE \\
\hline Employee Training & & \multirow[b]{2}{*}{0.877} & \multirow[b]{2}{*}{0.812} & \multirow[b]{2}{*}{0.641} \\
\hline $\begin{array}{l}\text { Continuous training } \\
\text { Informal training } \\
\text { Formal counseling practices } \\
\text { Continuity in education }\end{array}$ & $\begin{array}{l}0.844 * * * \\
0.754 * * * \\
0.782 * * * \\
0.819 * * *\end{array}$ & & & \\
\hline Strategies and Policies & & \multirow[b]{2}{*}{0.888} & \multirow[b]{2}{*}{0.854} & \multirow[b]{2}{*}{0.531} \\
\hline $\begin{array}{l}\text { Implementation of new ideas } \\
\text { Support for the development of ideas } \\
\text { Quick access to information } \\
\text { Procedures in support of innovation } \\
\text { Development of a bureaucratic system } \\
\text { Quick access to database } \\
\text { Unlimited access to information } \\
\end{array}$ & $\begin{array}{l}0.740 * * * \\
0.768 * * * \\
0.732 * * * \\
0.754 * * * \\
0.663 * * * \\
0.698 * * * \\
0.740 * * * \\
\end{array}$ & & & \\
\hline Acquisition of Knowledge & & \multirow[b]{2}{*}{0.849} & \multirow[b]{2}{*}{0.781} & \multirow[b]{2}{*}{0.531} \\
\hline $\begin{array}{l}\text { Knowledge of industrial sources } \\
\text { Knowledge of public bodies } \\
\text { Knowledge of external bodies } \\
\text { The internet is used to gain knowledge } \\
\text { Working with experts to gain knowledge }\end{array}$ & $\begin{array}{l}0.700 * * * \\
0.745 * * * \\
0.775 * * * \\
0.662 * * * \\
0.755 * * *\end{array}$ & & & \\
\hline Organizational Culture & & \multirow[b]{2}{*}{0.925} & \multirow[b]{2}{*}{0.892} & \multirow[b]{2}{*}{0.756} \\
\hline $\begin{array}{l}\text { Experiences are transmitted with employees } \\
\text { There is a system of values } \\
\text { Encourage to teamwork } \\
\text { Encourage to share knowledge }\end{array}$ & $\begin{array}{l}0.896^{* * *} \\
0.783^{* * *} \\
0.865^{* * *} \\
0.928 * * *\end{array}$ & & & \\
\hline \multicolumn{2}{|l|}{ Innovation } & \multirow[b]{2}{*}{0.903} & \multirow[b]{2}{*}{0.856} & \multirow[b]{2}{*}{0.699} \\
\hline $\begin{array}{l}\text { There are changes and/or improvements in products } \\
\text { New products are marketed } \\
\text { There are changes and/or improvements in the pro- } \\
\text { cesses } \\
\text { There is acquisition of new goods / equipment }\end{array}$ & $\begin{array}{l}0.873 * * * \\
0.802 * * * \\
0.862 * * * \\
0.804 * * *\end{array}$ & & & \\
\hline Performance & & \multirow[b]{2}{*}{0.910} & \multirow[b]{2}{*}{0.854} & \multirow[b]{2}{*}{0.772} \\
\hline $\begin{array}{l}\text { Increase in market share } \\
\text { Increase in productivity } \\
\text { Increase in profitability }\end{array}$ & $\begin{array}{l}0.863^{* * *} \\
0.898^{* * *} \\
0.874 * * *\end{array}$ & & & \\
\hline
\end{tabular}

$*: p<0.05, * *: p<0.01,{ }^{* * *}: p<0.001$

Finally, we checked discriminant validity of the constructs in the model by examining the square root of AVE. The results indicate that the AVE is more vertical and horizontal in relation to the correlation of the constructs that are below the diagonal (Gefen, Straub, \& Boudreau, 2000). This test does not detect any anomaly (see Table 4). Additionally, the results of the correlations between the constructs of the measurement model are presented. Obviously, our reflective constructs show good measures of both convergent and discriminant validity and reliability properties. 
Table 4: Discriminant validity of the theoretical model

\begin{tabular}{|l|c|c|c|c|c|c|c|}
\hline & AVE & Acquisition & $\begin{array}{c}\text { Cul- } \\
\text { ture }\end{array}$ & Training & Innovation & $\begin{array}{c}\text { Strategies } \\
\begin{array}{c}\text { Perfor- } \\
\text { mance }\end{array}\end{array}$ \\
\hline Acquisition of Knowledge & 0.531 & $\mathbf{0 . 7 2 9}$ & & & & & \\
\hline Organizational Culture & 0.756 & 0.425 & $\mathbf{0 . 8 7 0}$ & & & & \\
\hline Employee Training & 0.641 & 0.475 & 0.522 & $\mathbf{0 . 8 0 0}$ & & & \\
\hline Innovation & 0.699 & 0.331 & 0.358 & 0.311 & $\mathbf{0 . 8 3 6}$ & & $\mathbf{0 . 7 2 9}$ \\
\hline Strategies and Policies & 0.531 & 0.558 & 0.591 & 0.550 & 0.482 & 0.198 & $\mathbf{0 . 8 7 9}$ \\
\hline Performance & 0.772 & 0.116 & 0.144 & 0.104 & 0.201 & 0.198 \\
\hline
\end{tabular}

\section{Structural Model}

The statistical technique of structural equations based on variance was used to validate the hypotheses raised in this research and to verify the relationship among knowledge management, innovation (products and processes) and performance in SMEs through the SmartPLS Version 3.2.3 Professional (Ringle, Wende, \& Becker, 2014). The use of this software is appropriate in exploratory and confirmatory research (Chin, 2010; Urbach \& Ahlemann, 2010). Marcoulides and Saunders (2006) and Marcoulides, Chin, and Saunders (2009) suggest avoiding the mistake of believing that PLS must be used in all cases in which the sample size is small. Recently, it has been confirmed that the PLS can estimate values for samples which tend to infinity as well as for small samples (Henseler, Ringle, \& Sarstedt, 2012; Sarstedt et al., 2014). In Table 5 and Figure 2 the results of the coefficient $\beta$ and the significance of the distribution using Student's t test scores are shown. To verify the hypothesis, the procedure of bootstrapping with 5,000 subsamples was used as recommended by Chin (1998).

Table 5: Results of hypothesis tests

\begin{tabular}{|c|l|c|c|c|}
\hline Hypothesis & Beta Value & T Score & P Value & Rejected or Accepted \\
\hline Employee Training -> Innovation & 0.021 & 0.528 & 0.229 & Rejected \\
\hline Strategies and Policies - > Innovation & $0.375 * * *$ & 9.940 & 0.000 & Accepted \\
\hline Acquisition of Knowledge - > Innovation & $0.071 * *$ & 1.944 & 0.024 & Accepted \\
\hline Organizational Culture - > Innovation & $0.095 * * *$ & 2.541 & 0.006 & Accepted \\
\hline Innovation - > Performance & $0.201 * * *$ & 5.495 & 0.000 & Accepted \\
\hline
\end{tabular}

$*: p<0.05, * *: p<0.01, * * *: p<0.001$

To estimate the influence of the direct effect, which is the independent variable in the study on the dependent variable, the contrasts show the assumptions stated above. Table 5 shows the results of the PLS estimation. We found empirical support for most proposed hypotheses, except for $H 1$. In particular, according to the results of $H 2$ and $H 4$, empirical analysis suggests that the policies and strategies of management knowledge and organizational culture influence with greater intensity on innovation activities in SMEs $(\mathrm{p}<0.01)$. The $H 3$ shows that the acquisition of knowledge presents a lower intensity and influence on the activities of innovation in SMEs $(\mathrm{p}<0.05$ levels). In addition, with a strong intensity the $H 5$ indicates innovation activities to help SMEs increase their performance $(p<0.001)$. However, according to the test results $(\beta=0.021$, $\mathrm{p}=0.229$ ), training as part of KM has no significant influence on innovation in SMEs. Hypothesis $H 1$, is, thus, rejected. The beta coefficients of the hypothesized relationships range from $0.071^{* *}$ 
to $0.375^{* * *}$. Finally, we examined and tested the influence of the control variables, such as the size and age of the company. The size of the company was measured by the average number of employees in 2009, and the age was measured by the number of years since a company's creation and/or the beginning of its business activity. The test results using those control variables indicate that the size $(\beta=0.161, \mathrm{p}<0.001)$ and the age of a company $(\beta=0.050, \mathrm{p}<0.001)$ show positive and significant impacts on performance, indicating that these variables are important to the generation of improved performance in SMEs.

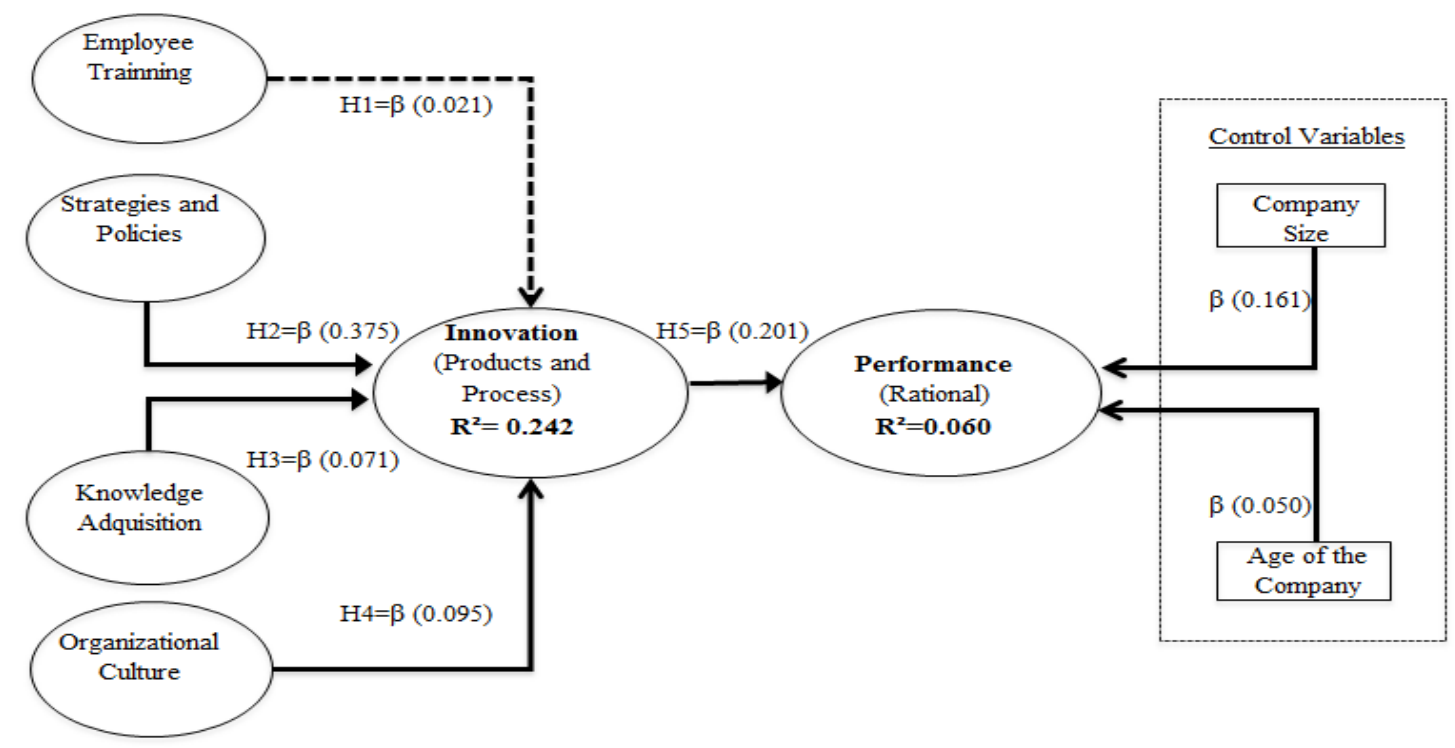

Figure 2. Research Model Supported by Empirical Data

PLS estimates, the variance as explained by $\left(\mathrm{R}^{2}\right)$, and the values of $\left(\mathrm{Q}^{2}\right)$ are important individual measures to explain the predictive power of the structural model (Chin, 2010). With respect to the analysis of variance explained by the model $\left(\mathrm{R}^{2}\right)$, which measures the predictive quality, the values of $0.1,0.25$ and 0.36 are small, medium, and large respectively (Wetzels et al., 2009). This review also examines the contribution of the predictor variables to the explained variance of the endogenous variables through the size of the path coefficients standardized with t-observed values and with the significance level obtained in the test with 5,000 bootstrap subsamples. The variance explained for variable innovation and performance are .242 and .060 , respectively. In our study, KM makes a medium contribution to innovation which exerts a small impact on performance in SMEs. The value of $\left(\mathrm{F}^{2}\right)$ measures the size of the effect/value introduced in the model. The values indicate a small effect of the model, with indicators ranging from 0.001 to 0.094 , as suggested by Chin (1998). The standardized path coefficients $(\beta)$ and $t$ values observed are significant after performing the bootstrapping test. Test $\left(\mathrm{Q}^{2}\right)$ is used to evaluate the predictive importance of the endogenous (reflective) constructs model. The model was evaluated with a blindfolding procedure through the $\left(\mathrm{Q}^{2}\right)$ statistic test (cross-validated redundancy index) (Hair, Hult, et al., 2013; Hair, Ringle, \& Sarstedt, 2013b). The results confirm that the structural model has satisfactory predictive significance for the variable innovation at 0.168 and yield of 0.041 . A value greater than (0) indicates that it has acceptable predictive notability (Hair et al., 2006). To explain more precisely the predictive effect of our model, we added a test of goodness of fit. When the Standardized Root Mean Squared Residual (SRMR) value is within the range of $(<0.08-0.1)$, it represents an acceptable adjustment of the model (Henseler et al., 2014). Our result of 0.043 is a good indicator of an acceptable model fit that predicts that the empirical data are aligned with the theory. 


\section{Discussion}

As we have observed, the management of knowledge allows a greater capacity for innovation and is a key factor for operational, economic, and financial achievement (López-Nicolás \& MeroñoCerdán, 2011; Noruzy et al., 2013). At the same time, innovation is needed so that companies can achieve and maintain their competitiveness in global markets with exponential changes that influence the development of new products and services (Çakar \& Ertürk, 2010; Madrid-Guijarro et al., 2009). Organizations with a low level of innovation will likely lose customers, quotas, and market share. Companies that are committed to adopting innovation can gain more customers, increase their sales, and reach new markets. In this section, we discuss our results in the context of the previous literature regarding the management of knowledge, innovation, and performance.

Our study shows that the adoption of KM in SMEs can provide a competitive advantage. Our analysis of the management of knowledge helps us to understand the conditions in which SMEs may be more effective in improving the processes of innovation and performance. One of the most important findings of this study focuses on the positive relationship between strategies and policies of the management of innovation in SMEs through knowledge. These results are consistent from a theoretical perspective, which indicates that the strategies and policies of KM generate more innovative personnel, thereby, increasing the intellectual capital (Bozbura et al., 2007; Gloet \& Terziovski, 2004). In addition, empirical studies indicate that KM policies and strategies are effective mechanisms for improving the business innovation of SMEs (Cantner et al., 2011; Constantinescu, 2009). When an organization deploys a strategy and sets policies based on the protection of the use of knowledge and works in an articulated form (Al-Hakim, 2013; Gebert, Boerner, \& Kearney, 2010; Velu, 2015), it can obtain high standards of knowledge and innovation (Adner \& Kapoor, 2010; N. Anderson, Potočnik, \& Zhou, 2014), which can impact business results (Alegre et al., 2013; Chesbrough, Vanhaverbeke, \& West, 2014).

Conversely, the effect that exists between the acquisition of knowledge and innovation in SMEs is positive. The literature indicates that the acquisition of external knowledge is one of the most basic corporate practices in the management of innovation (Arora et al., 2014; W. M. Cohen, 2010; W. M. Cohen \& Levinthal, 1990). It is important to consider that ICT plays an important role in the successful acquisition of knowledge (Augier \& Teece, 2009; Soliman, 2015) and innovation in SMEs (Lytras et al., 2010). The theory of resources and capabilities in relation to the use of ICT improves the acquisition of knowledge and allows for the minimization of costs in training and information gathering (Dalkir, 2013; Hill, Jones, \& Schilling, 2014; Sultan, 2013). Researchers have shown that KM is a determinant in increased sales, new product development, adaptations and improvements in innovation (Nawaz et al., 2014; C. Yu et al., 2013). Regarding the relationship between the organizational culture and innovation in SMEs, KM has been found to be a positive influence. These findings are similar to those of previous relevant studies (Senaji \& Nyaboga, 2011; Tseng \& Fan, 2011), which indicate that the organizational culture and corporate philosophy are essential elements for fostering innovation in SMEs. It is important to recognize that the most competitive organizations are adopting KM processes with a corporate culture based on the transfer and exchange of knowledge among employees (Delen et al., 2013; Michailova et al., 2013; Palacios-Marqués et al., 2015). These activities promote and strengthen the degree of innovation throughout the organization (Darvish \& Nazari, 2013).

With regard to the discovery of the relationship between the training of employees and business innovation, no significant positive relationship is found between the two. It can be inferred that SMEs are not currently investing in human capital formation. Some studies shown that most of the business fabrics in most part of Europe, and mainly in Spain, have stopped investing in the training of human resources (OECD, 2014b; United-Nations, 2015). Also with macroeconomic problems in the SMEs, the reduction in their workforce affected their innovation processes and the level of productivity (Bank-World, 2015; OECD, 2014a). A reasonable explanation of a non- 
significant influence between the training of employees and innovation can be derived from poor management of resources and capacities of SMEs. First, it is necessary to understand that these organizations are subtracting interest in the development and formation of human capital and only are focusing their resources on the everyday results (Riege, 2005; Yew Wong \& Aspinwall, 2005). Therefore, the operational and administrative staff is concentrated mainly in the operation of the business (J. B. Barney, 2001). Second an SME, by its nature, focuses its resources and internal expertise to develop innovation, forgetting the opportunities from the external environment (Chesbrough et al., 2014). These actions are leading to only insignificant results in product design and improvement of processes. The third point of analysis is that, in SMEs, it is common to observe in practice the use of economic models and traditional business (industrial economics) which reduces their chances of development and growth (Porter, 2011). The business practices of the leaders of these organizations lean mainly on short-term financial results (García-Teruel \& Martinez-Solano, 2007). It is important to SMEs to adopt a new global approach to business (transformation of capitalism and the evolutionary economic change theory) and to get involved the exchange of knowledge, learning, and processes with other organizations (cospecialization) providing additional value to their products and processes (Teece, 2007). These new trends and business are leading the organization to rediscover its dynamic capabilities in order to raise the level of innovation and competitiveness (Teece, 2007; Teece, Pisano, \& Shuen, 2009).

Theory and empirical studies suggest that companies should offer training to their employees to improve their skills to increase creativity and innovation (De Saá-Pérez et al., 2012; Nonaka, 2008; Schmitt, 2015). Companies are strengthening knowledge of their human capital to be more competitive and to improve the capacity for innovation (McIver, Lengnick-Hall, Lengnick-Hall, \& Ramachandran, 2013; Velu, 2015). Through training, companies are striving to generate greater intellectual capital (de Rassenfosse, 2011; Hislop, 2013). This business practice is a differentiating factor of an organization (Lepak \& Snell, 2007; Manuti et al., 2015).

This study provides new empirical evidence to support that the KM practices through innovation in products and processes improve SME performance. Our results have similarities to both the literature and the findings from some empirical studies (Choi et al., 2008; Noruzy et al., 2013; Vaccaro et al., 2010). Most of these studies claim that KM has an effect and a significant relationship to innovation and business performance. The size and age of a company are decisive factors in economic growth (Brouthers, Nakos, Hadjimarcou, \& Brouthers, 2009). The lifecycle (age of the company) is a key factor that may provide competitiveness and increase financial results (Bleda et al., 2013; Teece, 2007). Theory shows that the age of a company is correlated with the size of the organization; as a company ages, its size increases (Gavetti, 2012; Winter, 2005). Similarly, our results indicate that the size and age of the SMEs have a significant and positive effect on business performance. Finally, to respond to the objective and the research questions, the results of the proposed model to measure the management of knowledge and its influence on innovation show that this model provides appropriate indicators of predictive quality according to the statistical analyses. However, the influence on performance from innovation shows relatively low results according to the preset parameters. During the crisis and global economic downturn, in Spain the SMEs have presented serious problems to keep their competitiveness (OECD, 2014a). While several empirical studies indicate that innovation generates yields from economic and financial companies, the Spanish SMEs have not been able to lower some barriers relating to their internal processes and the rapidly changing external environment (OECD, 2014a). These obstacles relate mainly to the lack of funding from the government to business, zero investment in research and development R\&D (products and services), poor investment in ICT, and disarticulation of the business sector with research and universities centers (Demirbas, Hussain, \& Matlay, 2011; OECD, 2014a; Rüdiger, Peris-Ortiz, \& Blanco-González, 2013). In addition, total R\&D spending in Spain is relatively low compared with other European countries that are members of the OECD, due mainly to the low level of expenditure of the enterprises in this field (OECD, 
2014a, 2015b). These are some arguments and evidence which may warrant that innovation presents a low predictive quality on enterprise performance.

The results of this study have important implications for strengthening business management in SMEs. Managers must develop strategies that enable them to achieve greater innovation and business performance, and this can be achieved through the adoption of knowledge management (Huang et al., 2014; Ramírez, Vasauskaite, \& Kumpikaite, 2012; Vaccaro et al., 2010). First, those responsible for human resources management should provide training to employees to improve skills (Dixit \& Nanda, 2011) and should create a KM department that can function under the supervision of those responsible for each area (Bagnoli \& Vedovato, 2014; J. F. Cohen \& Olsen, 2015). Second, managers can increase the performance level of their organizations if they engage in the development of KM objectives using various techniques to improve knowledge and develop trust among employees (Černe et al., 2014; Hsu, 2008). Additionally, SME managers should open their minds to changes and effectively adopt knowledge management (Yeşil \& Hirlak, 2013), which can provide an important source of business results and advantages (Mangiarotti \& Mention, 2015). Managers should be aware that companies with greater predispositions to innovate encourage the development of new products, services, and processes (Fraj Andrés, Matute Vallejo, \& Melero Polo, 2013; Valdez \& Maldonado, 2015).

The research also involves the following limitations and, conversely, opens the door for the development of future lines of research. One limitation is the use of a single source of information. Because the data were obtained from self-reported and subjective perceptions of the owners or managers of SMEs, this may skew the results. Second, the study focused on companies in industry, construction, services, and trade only. Future analyses could extend the sample to other business sectors and consider a comparative study design between SMEs and large corporations. In addition, the sample included the perceptions of managers of knowledge management processes, which opens the possibility of exploring the opinions of companies' employees. The last limitation considered in this paper involves the measurement scales used for the management of knowledge. This study solely considered variables of the reflective type with adaptations of scales from other researchers. It would be interesting to use other types of variables, such as reflectiveformative variables.

\section{Conclusion}

The study has analyzed the influence of KM on SMEs' innovation and performance during a recent period of global economic recession. The results were based on data collected through a questionnaire administered to a sample of small and medium-sized companies in the sectors of industry, construction, services, and trade in the region of Murcia, Spain. The results indicate that (1) in SMEs, there is no mechanism for training employees, therefore, SMEs should allocate greater financial resources to training programs to achieve greater creativity to improve innovation; (2) although SMEs have certain practices for the acquisition of knowledge, it is important that new actions and strategies are considered, such as the use of ICT; (3) SMEs must continue with the establishment of policies and strategies, both in the acquisition and the use of knowledge and the deployment of an organizational culture, based on values to allow a further strengthening of innovation activities; and (4) the level of influence of innovation on performance in SMEs is relatively low. Most of these companies have serious limitations in their organizational and financial management, causing a poor capacity to innovate (Lichtenthaler, 2011). To increase the level of innovation and creativity, it's not enough to invest in R\&D and in reward systems (Lahi \& Elenurm, 2014). The business owners should consider implementing strategies focused on the development of new business models, new technologies, and the incorporation of open innovation (Herzog \& Leker, 2011; Teece, 2007). It is also convenient to develop alliances and external networks to acquire, transfer, and exploit external knowledge (Pai \& Chang, 2013; Teece, 2007). 
With a model based on the dynamic capabilities (knowledge absorption, knowledge integration and reconfiguration of knowledge) SMEs can improve their products, processes, intellectual property, satisfy customers and achieve sustained competitive advantage approach (Biere, 2010; Teece, 2007).

In most parts of the world, the organizations that provide considerable contributions to the economy are SMEs (Lenihan, Andr, \& Hart, 2010; OECD, 2015a). Despite recent crises and economic recessions, SMEs continue to contribute to the gross domestic product (GDP) and the generation of employment in many countries (Baptista \& Leitão, 2015; Levy-Dabbah, 2005; OECD, 2014b). To take a step toward consolidation and growth (Bascavusoglu-Moreau \& Colakoglu, 2013; Kyaruzi, 2008), these companies must use as a reference the business models and KM processes of large companies (Chan \& Chao, 2008; Edvardsson \& Durst, 2013). SMEs have distinguished themselves by their lack of medium- and long-term plans (Theriou, Maditinos, \& Theriou, 2010), resulting in limitations and difficulties in adopting a KM strategy (Gray, 2006; Pillania, 2013; Sparrow, 2010). These limitations often relate to the size of the company; that is, when a company is small or medium, it may be confronted with problems of financial budget, shortage of trained human resources, high staff turnover, lack of motivation, tacit knowledge, little interest from managers, and obsolete infrastructure (Lee \& Lan, 2011; Uma Mageswari, Sivasubramanian, \& Srikantha Dath, 2015). Furthermore, globalization and new ICTs represent difficulties due to constant technological change and high costs (Hu, Sharif, \& Baark, 2014; Velu, 2015). Recently, these barriers have become an opportunity for growth and development for SMEs (Hota, Upadhyaya, \& Al-Karaki, 2015; Kamel, 2010). These opportunities can be leveraged through resources and capacities. As companies grow in size (number of employees, total assets and income), they move toward a stage of maturity and consolidate themselves in this new era of the knowledge economy.

In the future, in addition to addressing the constraints, the conceptual model will be improved through the inclusion of a greater number of constructs that will contribute to the development of business practices in SMEs. It is appropriate to incorporate variables that continuously analyze the behavior of SMEs in different areas of their business management. The KM of collaboration and virtual knowledge has recently emerged, supported by new ICT and innovative tools such as Web 2.0 (Oncioiu, 2013; Sankar \& Bouchard, 2009) and Web 3.0 (L. Harris, Rae, \& Misner, 2012; Schatten, 2013). These new approaches can contribute to the proposed model by measuring knowledge management in SMEs. These new tools should be properly used in organizations with feedback from managers and experts in the field. The emergence of new hybrid models can improve the behavior and the benefits of companies' KM. Finally, given the importance of knowledge management in knowledge-based societies, research on the following issues is suggested: managers' leadership styles and their influence on the effectiveness of the management of knowledge and the relationship between ICT and knowledge management processes and, in turn, innovation. It would also be interesting to analyze the behavior of the relationship between knowledge management and dynamic capabilities on business performance. In addition, it is necessary to continually evaluate the degree of performance and competitiveness of such organizations with longitudinal studies. 


\section{References}

Abdolvahabi, M., Sofiyabadi, J., Abdolvahabi, M., \& Valmohammadi, C. (2014). Case on e-learning and knowledge management practices. Asian Journal of Research in Business Economics and Management, 4, 264-276.

Abdul-Jalal, H., Toulson, P., \& Tweed, D. (2013). Knowledge sharing success for sustaining organizational competitive advantage. Procedia Economics and Finance, 7, 150-157.

Adner, R., \& Kapoor, R. (2010). Value creation in innovation ecosystems: How the structure of technological interdependence affects firm performance in new technology generations. Strategic Management Journal, 31, 306-333.

Al-Hakim, L. (2013). Quality innovation: Knowledge, theory, and practices. Hershey, PA: IGI Global.

Alegre, J., Sengupta, K., \& Lapiedra, R. (2013). Knowledge management and innovation performance in a high-tech SMEs industry. International Small Business Journal, 31, 454-470.

Amidon, D. M., Formica, P., Mercier-Laurent, E., \& Ülikool, T. (2005). Knowledge economics: Emerging principles, practices and policies. Tartu, Estonia: University of Tartu, Faculty of Economics and Business Administration.

Aming'a, N. (2015). Knowledge capture and acquisition mechanisms at Kisii University. Interdisciplinary Journal of Information, Knowledge, and Management, 10, 105-116. Retrieved from http://www.informingscience.org/Publications/2284

Anand, A., Kant, R., Patel, D. P., \& Singh, M. D. (2012). Knowledge management implementation: A predictive model using an analytical hierarchical process. Journal of the Knowledge Economy, 6, 4871.

Anderson, B. S., \& Eshima, Y. (2013). The influence of firm age and intangible resources on the relationship between entrepreneurial orientation and firm growth among Japanese SMEs. Journal of Business Venturing, 28, 413-429. doi:10.1016/j.jbusvent.2011.10.001

Anderson, N., Potočnik, K., \& Zhou, J. (2014). Innovation and creativity in organizations a state-of-thescience review, prospective commentary, and guiding framework. Journal of Management, 40, 12971333.

Andrés, A. R., Asongu, S. A., \& Amavilah, V. (2014). The impact of formal institutions on knowledge economy. Journal of the Knowledge Economy, 6, 1-29.

Arora, A., Belenzon, S., \& Rios, L. A. (2014). Make, buy, organize: The interplay between research, external knowledge, and firm structure. Strategic Management Journal, 35, 317-337.

Asare, S. D., Gopolang, B., \& Mogotlhwane, O. (2012). Challenges facing SMEs in the adoption of ICT in B2B and B2C E-commerce: A comparative case study of Botswana and Ghana. International Journal of Commerce and Management, 22, 272-285.

Asif, M., de Vries, H. J., \& Ahmad, N. (2013). Knowledge creation through quality management. Total Quality Management \& Business Excellence, 24, 664-677.

Augier, M., \& Teece, D. J. (2009). Dynamic capabilities and the role of managers in business strategy and economic performance. Organization Science, 20, 410-421.

Bagnoli, C., \& Vedovato, M. (2014). The impact of knowledge management and strategy configuration coherence on SME performance. Journal of Management \& Governance, 18, 615-647.

Bagozzi, R. P., \& Yi, Y. (2012). Specification, evaluation, and interpretation of structural equation models. Journal of the Academy of Marketing Science, 40, 8-34.

Bank-World. (2015). Global economic prospects, June 2015: The global economy in transition. Washington, DC: World Bank Publications. 
Baptista, R., \& Leitão, J. (2015). Entrepreneurship, human capital, and regional development: Labor networks, knowledge flows, and industry growth. Cham, Switzerland: Springer International Publishing.

Barclay, D., Higgins, C., \& Thompson, R. (1995). The partial least squares (PLS) approach to causal modeling: Personal computer adoption and use as an illustration. Technology Studies, 2, 285-309.

Barney, J. (1991). Firm resources and sustained competitive advantage. Journal of Management, 17, 99120. doi:10.1177/014920639101700108

Barney, J. B. (2001). Resource-based theories of competitive advantage: A ten-year retrospective on the resource-based view. Journal of Management, 27, 643-650.

Bartol, K. M., \& Srivastava, A. (2002). Encouraging knowledge sharing: The role of organizational reward systems. Journal of Leadership \& Organizational Studies, 9, 64-76.

Bascavusoglu-Moreau, E., \& Colakoglu, M. (2013). Impact of SME policies on innovation capabilities: The Turkish case. In I. H. Yetkiner (Ed.), Industrial dynamics, Innovation policy, and economic growth through technological advancements (pp. 159-184). Hershey, PA: IGI Global.

Battistella, C., De Toni, A. F., \& Pillon, R. (2015). Inter-organisational technology/knowledge transfer: A framework from critical literature review. The Journal of Technology Transfer, 1-40.

Becerra-Fernandez, I., \& Sabherwal, R. (2014). Knowledge management: Systems and processes. New York, NY: Routledge.

Benitez-Amado, J., \& Walczuch, R. M. (2012). Information technology, the organizational capability of proactive corporate environmental strategy and firm performance: A resource-based analysis. European Journal of Information Systems, 21, 664-679.

Berce, J., Lanfranco, S., \& Vehovar, V. (2008). eGovernance: Information and communication technology, knowledge management and learning organisation culture. Informatica, 32, 189-205.

Biere, M. (2010). The new era of enterprise business intelligence: Using analytics to achieve a global competitive advantage. Upper Saddle River, NJ: Pearson Education.

Bleda, M., Morrison, K., \& Rigby, J. (2013). The role and importance of gazelles and other growth firms for innovation and competitiveness. Innovation Policy Challenges for the 21st Century, 27, 110.

Blumentritt, T., \& Danis, W. M. (2006). Business strategy types and innovative practices. Journal of Managerial Issues, 18, 274-291.

Bollen, K., \& Lennox, R. (1991). Conventional wisdom on measurement: A structural equation perspective. Psychological Bulletin, 110, 305-314. doi:10.1037/0033-2909.110.2.305

Bontis, N. (2001). Assessing knowledge assets: A review of the models used to measure intellectual capital. International Journal of Management Reviews, 3, 41-60.

Bontis, N., Bart, C. K., Nazari, J. A., \& Herremans, I. M. (2007). Extended VAIC model: Measuring intellectual capital components. Journal of Intellectual Capital, 8, 595-609.

Bontis, N., Wu, S., Wang, W.-Y., \& Chang, C. (2005). Intellectual capital and performance in causal models: Evidence from the information technology industry in Taiwan. Journal of Intellectual Capital, $6,222-236$.

Boyes, W. (2011). Managerial economics: Markets and the firm. Mason, OH: Cengage Learning.

Bozbura, F. T., Beskese, A., \& Kahraman, C. (2007). Prioritization of human capital measurement indicators using fuzzy AHP. Expert Systems with Applications, 32, 1100-1112.

Brouthers, L. E., Nakos, G., Hadjimarcou, J., \& Brouthers, K. D. (2009). Key factors for successful export performance for small firms. Journal of International Marketing, 17, 21-38. 
Burcharth, A. L. d. A., Knudsen, M. P., \& Søndergaard, H. A. (2014). Neither invented nor shared here: The impact and management of attitudes for the adoption of open innovation practices. Technovation, 34, 149-161. doi:10.1016/j.technovation.2013.11.007

Çakar, N. D., \& Ertürk, A. (2010). Comparing innovation capability of small and medium-sized enterprises: Examining the effects of organizational culture and empowerment. Journal of Small Business Management, 48, 325-359. doi:10.1111/j.1540-627X.2010.00297.x

Cannella, A. A., \& McFadyen, M. A. (2013). Changing the exchange the dynamics of knowledge worker ego networks. Journal of Management, 42, 1005-1029.

Cantner, U., Joel, K., \& Schmidt, T. (2011). The effects of knowledge management on innovative success An empirical analysis of German firms. Research Policy, 40, 1453-1462. doi:10.1016/j.respol.2011.06.007

Caragliu, A., \& Nijkamp, P. (2012). The impact of regional absorptive capacity on spatial knowledge spillovers:Tthe Cohen and Levinthal model revisited. Applied Economics, 44, 1363-1374.

Carmines, E. G., \& Zeller, R. A. (1991). Reliability and viability assessment. Thousand Oaks, CA: Sage.

Carrillo, F. J., Schiuma, G., \& Lerro, A. (2008). Knowledge-based capital in building regional innovation capacity. Journal of Knowledge Management, 12, 121-136.

Cavaliere, V., \& Lombardi, S. (2015). Exploring different cultural configurations: How do they affect subsidiaries' knowledge sharing behaviors? Journal of Knowledge Management, 19, 141-163.

Černe, M., Nerstad, C. G. L., Dysvik, A., \& Škerlavaj, M. (2014). What goes around comes around: Knowledge hiding, perceived motivational climate, and creativity. Academy of Management Journal, $57,172-192$.

Chan, I., \& Chao, C.-K. (2008). Knowledge management in small and medium-sized enterprises. Communications of the ACM, 51, 83-88.

Chang, S.-C., \& Lee, M.-S. (2008). The linkage between knowledge accumulation capability and organizational innovation. Journal of Knowledge Management, 12, 3-20.

Chen, Y. Y., \& Huang, H.-L. (2012). Knowledge management fit and its implications for business performance: A profile deviation analysis. Knowledge-based Systems, 27, 262-270.

Chen, Y. Y., \& Jaw, Y.-L. (2009). Building global dynamic capabilities through innovation: A case study of Taiwan's cultural organizations. Journal of Engineering and Technology Management, 26, 247-263.

Chen, Y. Y., Lin, M.-J. J., \& Chang, C.-H. (2009). The positive effects of relationship learning and absorptive capacity on innovation performance and competitive advantage in industrial markets. Industrial Marketing Management, 38, 152-158.

Chesbrough, H. W., Vanhaverbeke, W., \& West, J. (2014). New frontiers in open innovation. Oxford, UK: Oxford University Press.

Chin, W. W. (1998). The partial least squares approach to structural equation modeling. Modern Methods for Business Research, 295, 295-336.

Chin, W. W. (2010). How to write up and report PLS analyses. In V. E. Vinzi, W. W. Chin, J. Henseler, \& H. Wang (Eds.), Handbook of partial least squares (pp. 655-690). Berlin Heidelberg: Spinger-Verlag.

Chin, W. W., \& Dibbern, J. (2010). An introduction to a permutation based procedure for multi-group PLS analysis: Results of tests of differences on simulated data and a cross cultural analysis of the sourcing of information system services between Germany and the USA. In V. E. Vinzi, W. W. Chin, J. Henseler, \& H. Wang (Eds.), Handbook of partial least squares (pp. 171-193). Berlin Heidelberg: Springer-Verlag.

Choi, B., Poon, S., \& Davis, J. (2008). Effects of knowledge management strategy on organizational performance: A complementarity theory-based approach. Omega, 36, 235-251. doi:10.1016/j.omega.2006.06.007 
Chuang, S.-H. (2004). A resource-based perspective on knowledge management capability and competitive advantage: An empirical investigation. Expert Systems with Applications, 27, 459-465. doi:10.1016/j.eswa.2004.05.008

Coad, A., \& Hölzl, W. (2012). 24 Firm growth: Empirical analysis. In M. Dietrich \& J. Krafft (Eds.), Handbook on the economics and theory of the firm (pp. 324-338). Cheltenham, UK: Edward Elgar Publishing.

Cohen, J. F., \& Olsen, K. (2015). Knowledge management capabilities and firm performance: A test of universalistic, contingency and complementarity perspectives. Expert Systems with Applications, 42, 1178-1188. doi:10.1016/j.eswa.2014.09.002

Cohen, W. M. (2010). Fifty years of empirical studies of innovative activity and performance. Handbook of the Economics of Innovation, 1, 129-213.

Cohen, W. M., \& Levinthal, D. A. (1990). Absorptive capacity: A new perspective on learning and innovation. Administrative Science Quarterly, 35, 128-152.

Constantinescu, M. (2009). Knowledge management: Focus on innovation and labor productivity in a knowledge-based economy. IUP Journal of Knowledge Management, 7, 7.

Dalkir, K. (2013). Knowledge management in theory and practice. Hoboken, NJ: Taylor and Francis.

Darroch, J. (2005). Knowledge management, innovation and firm performance. Journal of Knowledge Management, 9, 101-115. doi:10.1108/13673270510602809

Darroch, J., \& McNaughton, R. (2002). Examining the link between knowledge management practices and types of innovation. Journal of Intellectual Capital, 3, 210-222. doi:10.1108/14691930210435570

Darvish, H., Mohammadi, M., \& Afsharpour, P. (2012). Studying the knowledge management, effect of promoting the pour Balanced Scorecard perspectives: A case study at SAIPA Automobile Manufacturing. Economic Insights Trends and Challenges, 64, 9-23.

Darvish, H., \& Nazari, E. A. (2013). Organizational learning culture-The missing link between innovative culture and innovations (case study: Saderat Bank of Iran). Econ Insights-Trends Challenges, 65, 116.

Davenport, T. H. (1994). Saving IT's soul: Human-centered information management. Harvard Business Review, 72, 119-131.

Davenport, T. H. (2013). Process innovation:Rreengineering work through information technology. Cambridge, MA: Harvard Business Press.

Davenport, T. H., \& Prusak, L. (1998). Working knowledge: How organizations manage what they know. Cambridge, MA: Harvard Business Press.

Davenport, T. H., Thomas, R. J., \& Cantrell, S. (2012). The mysterious art and science of knowledgeworker performance. MIT Sloan Management Review, 44.

de Rassenfosse, G. (2011). How SMEs exploit their intellectual property assets: Evidence from survey data. Small Business Economics, 39, 437-452. doi:10.1007/s11187-010-9313-4

De Saá-Pérez, P., Díaz-Díaz, N. L., \& Luis Ballesteros-Rodriguez, J. (2012). The role of training to innovate in SMEs. Innovation, 14, 218-230.

Dekimpe, M. G., \& Hanssens, D. M. (2004). Persistence modeling for assessing marketing strategy performance.

Delen, D., Zaim, H., Kuzey, C., \& Zaim, S. (2013). A comparative analysis of machine learning systems for measuring the impact of knowledge management practices. Decision Support Systems, 54, 11501160 .

Demirbas, D., Hussain, J. G., \& Matlay, H. (2011). Owner-managers' perceptions of barriers to innovation: Empirical evidence from Turkish SMEs. Journal of Small Business and Enterprise Development, 18, 764-780. 
Dixit, G. K., \& Nanda, T. (2011). Strategic alignment of organizational culture and climate for stimulating innovation in SMEs. International Journal of Innovation, Management and Technology, 2, 77-85.

Drucker, P. F. (1999). Knowledge-worker productivity: The biggest challenge. California Management Review, 41, 79-94.

Duhon, B. (1998). It's all in our heads. Inform, 12, 8-13.

Durst, S., Edvardsson, I. R., \& Bruns, G. (2013). Knowledge creation in small building and construction firms. Journal of Innovation Management, 1, 125-142.

Durst, S., \& Edvardsson, I. R. (2012). Knowledge management in SMEs: A literature review. Journal of Knowledge Management, 16, 879-903. doi:10.1108/13673271211276173

Ebrahimi, M., \& Sadeghi, M. (2013). Quality management and performance: An annotated review. International Journal of Production Research, 51, 5625-5643.

Edvardsson, I. R., \& Durst, S. (2013). The benefits of knowledge management in small and medium-sized enterprises. Procedia-Social and Behavioral Sciences, 81, 351-354.

Eisenberg, T., Sundgren, S., \& Wells, M. T. (1998). Larger board size and decreasing firm value in small firms. Journal of Financial Economics, 48, 35-54.

Esposito Vinzi, V., Chin, W. W., Henseler, J., \& Wang, H. (2010). Handbook of partial least squares: Concepts, methods and applications. Berlin Heidelberg: Springer-Verlag.

Falk, R. F., \& Miller, N. B. (1992). A primer for soft modeling. Akron, OH: University of Akron Press.

Foray, D. (2004). Economics of knowledge. Cambridge, MA: MIT Press.

Fornell, C., \& Larcker, D. F. (1981). Structural equation models with unobservable variables and measurement error: Algebra and statistics. Journal of Marketing Research, 18, 382-388.

Foss, N. J., Husted, K., \& Michailova, S. (2010). Governing knowledge sharing in organizations: Levels of analysis, governance mechanisms, and research directions. Journal of Management Studies, 47, 455482.

Fraj Andrés, E., Matute Vallejo, J., \& Melero Polo, I. (2013). El aprendizaje y la innovación como determinantes del desarrollo de una capacidad de gestión medioambiental proactiva. Cuadernos de Economía y Dirección de la Empresa, 16, 180-193. doi:10.1016/j.cede.2012.10.001

Friedman, B. M. (2006). The moral consequences of economic growth. Society, 43, 15-22.

Fullan, M. (2014). Leading in a culture of change personal action guide and workbook. New York, NY: John Wiley \& Sons.

Gallié, E.-P., \& Legros, D. (2012). Firms' human capital, R\&D and innovation: a study on French firms. Empirical Economics, 43, 581-596.

Garavan, T., O’Brien, F., \& Murphy, E. (2014). Knowledge management in small and medium-sized enterprises: Navigating informality and resource constraints. In A. Örtenblad (Ed.), Handbook of research on knowledge management: Adaptation and context (pp. 189-207). Cheltenham, UK: Edward Elgar Publishing.

García-Teruel, P. J., \& Martinez-Solano, P. (2007). Effects of working capital management on SME profitability. International Journal of Managerial Finance, 3, 164-177.

Gavetti, G. (2012). PERSPECTIVE-Toward a behavioral theory of strategy. Organization Science, 23, 267-285.

Gebert, D., Boerner, S., \& Kearney, E. (2010). Fostering team innovation: Why is it important to combine opposing action strategies? Organization Science, 21, 593-608.

Gefen, D., Straub, D., \& Boudreau, M.-C. (2000). Structural equation modeling and regression: Guidelines for research practice. Communications of the Association for Information Systems, 4, 7. 
Geyskens, I., Gielens, K., \& Gijsbrechts, E. (2010). Proliferating private-label portfolios: How introducing economy and premium private labels influences brand choice. Journal of Marketing Research, 47, 791-807.

Gloet, M., \& Terziovski, M. (2004). Exploring the relationship between knowledge management practices and innovation performance. Journal of Manufacturing Technology Management, 15, 402-409. doi:10.1108/17410380410540390

Gold, A. H., Malhotra, A., \& Segars, A. H. (2001). Knowledge management: An organizational capabilities perspective. Journal of Management Information Systems, 18, 185-214.

Gray, C. (2006). Absorptive capacity, knowledge management and innovation in entrepreneurial small firms. International Journal of Entrepreneurial Behavior \& Research, 12, 345-360. doi:10.1108/13552550610710144

Hair, J. F., Black, W. C., Babin, B. J., Anderson, R. E., \& Tatham, R. L. (2006). Multivariate data analysis. Upper Saddle River, NJ: Pearson Prentice Hall.

Hair, J. F., Black, W. C., Babin, B. J., Anderson, R. E., \& Tatham, R. L. (2010). SEM: An introduction Multivariate data analysis: A global perspective (pp. 629-686). Upper Saddle River, NJ: Pearson Education.

Hair, J. F., Hult, G. T. M., Ringle, C., \& Sarstedt, M. (2013). A primer on partial least squares structural equation modeling (PLS-SEM). Los Angeles, CA: Sage Publications.

Hair, J. F., Ringle, C. M., \& Sarstedt, M. (2013). Editorial-partial least squares structural equation modeling: Rigorous applications, better results and higher acceptance. Long range planning, 46, 1-12.

Hansen, M. T., Nohria, N., \& Tierney, T. (2005). What's your strategy for managing knowledge. Knowledge Management: Critical Perspectives on Business and Management, 77, 322.

Harris, L., Rae, A., \& Misner, I. (2012). Punching above their weight: The changing role of networking in SMEs. Journal of Small Business and Enterprise Development, 19, 335-351.

Harris, R., McAdam, R., McCausland, I., \& Reid, R. (2013). Knowledge management as a source of innovation and competitive advantage for SMEs in peripheral regions. The International Journal of Entrepreneurship and Innovation, 14, 49-61.

Henseler, J., Dijkstra, T. K., Sarstedt, M., Ringle, C. M., Diamantopoulos, A., Straub, D. W., . . . Calantone, R. J. (2014). Common beliefs and reality about PLS comments on Rönkkö and Evermann (2013). Organizational Research Methods, 17, 182-209.

Henseler, J., Ringle, C. M., \& Sarstedt, M. (2012). 12 Using partial least squares path modeling in advertising research: Basic concepts and recent issues. In S. Okazaki (Ed.), Handbook of research on international advertising (pp. 252). Cheltenham, UK: Edward Elgar.

Henseler, J., Ringle, C. M., \& Sarstedt, M. (2015). A new criterion for assessing discriminant validity in variance-based structural equation modeling. Journal of the Academy of Marketing Science, 43, 115135 .

Herzog, P., \& Leker, J. (2011). Open and closed innovation: Different cultures for different strategies. Wiesbaden, Germany: Gabler Verlag.

Hill, C., Jones, G., \& Schilling, M. (2014). Strategic management: Theory: An integrated approach. Mason, OH: Cengage Learning.

Hislop, D. (2013). Knowledge management in organizations: A critical introduction. Oxford, UK: OUP Oxford.

Hofstede, G., Hofstede, G. J., \& Minkov, M. (2010). Cultures et organisations: Nos programmations mentales. Paris, France: Pearson Education France.

Holsapple, C. (2013). Handbook on knowledge management 1: Knowledge matters. Berlin Heidelberg: Springer Science \& Business Media. 
Horte, S. A., Barth, H., Chibba, A., Florén, H., Frishammar, J., Halila, F., . . Tell, J. (2008). Product development in SMEs: a literature review. International Journal of Technology Intelligence and Planning, 4, 299-325.

Hota, C., Upadhyaya, S., \& Al-Karaki, J. N. (2015). Advances in secure knowledge management in the big data era. Information Systems Frontiers, 17, 983-986.

Hsu, I. C. (2008). Knowledge sharing practices as a facilitating factor for improving organizational performance through human capital: A preliminary test. Expert Systems with Applications, 35, 13161326. doi:10.1016/j.eswa.2007.08.012

Hu, M.-C., Sharif, N., \& Baark, E. (2014). Information technology services: A key knowledge-intensive business service industry in Hong Kong SAR, China. Science Technology \& Society, 19, 27-55.

Huang, Y., Wang, X. J., Gardoni, M., \& Amadou, C. (2014). A knowledge integration methodology for developing customized maintenance document. Interdisciplinary Journal of Information, Knowledge, and Management, 9, 175-191. Retrieved from http://www.informingscience.org/Publications/2080

Hughes, A. (2001). Innovation and business performance: Small entrepreneurial firms in the UK and the EU. New Economy, 8, 157-163.

Hughes, B., \& Wareham, J. (2010). Knowledge arbitrage in global pharma: A synthetic view of absorptive capacity and open innovation. R\&D Management, 40, 324-343.

Ikujiro, N., \& Hiroshi, Y. (2013). Eastern and western knowledge creating dialectical dynamism. Journal of the Japanese Society for Artificial Intelligence, 28, 465-467.

Imran, M. K. (2014). Impact of knowledge management infrastructure on organizational performance with moderating role of KM performance: An empirical study on banking sector of Pakistan. Information and Knowledge Management, 4(8), 85-98.

INE. (2010). Instituto nacional de estadística. Directorio central de empresas: Explotación estadística. Retrieved from http://www.ine.es/

Jarvis, C. B., MacKenzie, S. B., \& Podsakoff, P. M. (2003). A critical review of construct indicators and measurement model misspecification in marketing and consumer research. Journal of Consumer Research, 30, 199-218.

Jayasingam, S., Ansari, M. A., Ramayah, T., \& Jantan, M. (2013). Knowledge management practices and performance: Are they truly linked? Knowledge Management Research \& Practice, 11, 255-264.

Jelavic, M. (2011). Socio-technical knowledge management and epistemological paradigms: Theoretical connections at the individual and organisational level. Interdisciplinary Journal of Information, Knowledge, and Management, 6, 1-16. Retrieved from http://www.informingscience.org/Publications/1337

Jensen, C., \& Peng, L. M. (2013). SMEs, institutions, and performance. In Information Resources Management Association (Ed.), Small and medium enterprises: Concepts, methodologies, tools, and applications (pp. 46-64). Hershey, PA: IGI Global.

Jensen, M. B., Johnson, B., Lorenz, E., \& Lundvall, B. Å. (2007). Forms of knowledge and modes of innovation. Research Policy, 36, 680-693.

Kale, S., \& Karaman, E. A. (2012). A diagnostic model for assessing the knowledge management practices of construction firms. KSCE Journal of Civil Engineering, 16, 526-537.

Kalyanaram, G., Robinson, W. T., \& Urban, G. L. (1995). Order of market entry: Established empirical generalizations, emerging empirical generalizations, and future research. Marketing Science, 14, G212G221. doi:10.1287/mksc.14.3.G212

Kamel, S. (2010). E-strategies for technological diffusion and adoption: National ICT approaches for socioeconomic development: national ICT approaches for socioeconomic development. Hershey, PA: IGI Global. 
Kamyabi, Y., \& Devi, S. (2012). The impact of advisory services on Iranian SME performance: An empirical investigation of the role of professional accountants. South African Journal of Business Management, 43, 61-72.

Kaplan, R. S., Norton, D. P., \& Rugelsjoen, B. (2010). Managing alliances with the balanced scorecard. Harvard Business Review, 88, 114-120.

Kostopoulos, K., Papalexandris, A., Papachroni, M., \& Ioannou, G. (2011). Absorptive capacity, innovation, and financial performance. Journal of Business Research, 64, 1335-1343. doi:10.1016/j.jbusres.2010.12.005

Kristandl, G., \& Bontis, N. (2007). Constructing a definition for intangibles using the resource based view of the firm. Management Decision, 45, 1510-1524. doi:10.1108/00251740710828744

Kyaruzi, I. S. (2008). African businesses and economic growth:Iinstitutions, firms, practice and policy. London, UK: Adonis \& Abbey.

Lahi, A., \& Elenurm, T. (2014). Catalysts and barriers of open innovation for SMEs in transition economy. In Proceedings of the 2nd International Conference on Innovation and Entrepreneurship: ICIE 2014, (pp. 149).

Lai, Y.-L., Hsu, M.-S., Lin, F.-J., Chen, Y.-M., \& Lin, Y.-H. (2014). The effects of industry cluster knowledge management on innovation performance. Journal of Business Research, 67, 734-739. doi:10.1016/j.jbusres.2013.11.036

Lavergne, R., \& Earl, R. L. (2006). Knowledge management: A value creation perspective. Journal of Organizational Culture, Communication and Conflict, 10, 43.

Lee, M. R., \& Lan, Y.-C. (2011). Toward a unified knowledge management model for SMEs. Expert Systems with Applications, 38, 729-735.

Leiponen, A., \& Helfat, C. E. (2010). Innovation objectives, knowledge sources, and the benefits of breadth. Strategic Management Journal, 31, 224-236.

Lenihan, H., Andr, B., \& Hart, M. (2010). SMEs in a globalised world: Survival and growth strategies on Europe's geographical periphery. Cheltenham, UK: Edward Elgar Publishing.

Lepak, D., \& Snell, S. A. (2007). Employment subsystems and the'HR architecture'. In P. Boxall, J. Purcell, $\&$ P. Wright (Eds.), The Oxford handbook of human resource management (pp. 210-230). Oxford, UK: Oxford University Press.

Levy-Dabbah, S. (2005). China, la nueva fábrica del mundo. Mexico: Ediciones Fiscales ISEF.

Lichtenthaler, U. (2011). Open innovation: Past research, current debates, and future directions. The Academy of Management Perspectives, 25, 75-93.

Lin, C., Wu, J.-C., \& Yen, D. C. (2012). Exploring barriers to knowledge flow at different knowledge management maturity stages. Information \& Management, 49, 10-23.

Lin, W.-B. (2008). The effect of knowledge sharing model. Expert Systems with Applications, 34, 15081521 .

Linderman, K., Schroeder, R. G., \& Sanders, J. (2010). A knowledge framework underlying process management. Decision Sciences, 41, 689-719.

López-Nicolás, C., \& Meroño-Cerdán, Á. L. (2011). Strategic knowledge management, innovation and performance. International Journal of Information Management, 31, 502-509. doi:10.1016/j.ijinfomgt.2011.02.003

Lopez-Nicolas, C., \& Soto-Acosta, P. (2010). Analyzing ICT adoption and use effects on knowledge creation: An empirical investigation in SMEs. International Journal of Information Management, 30, 521-528. 
Lytras, M. D., De Pablos, P. O., Ziderman, A., Roulstone, A., Maurer, H., \& Imber, J. B. (2010). Knowledge management, information systems, e-learning, and sustainability research. In Third World Summit on the Knowledge Society, WSKS 2010, (pp. Corfu, Greece.

Madrid-Guijarro, A., Garcia, D., \& Van Auken, H. (2009). Barriers to innovation among Spanish manufacturing SMEs. Journal of Small Business Management, 47, 465-488. doi:10.1111/j.1540627X.2009.00279.X

Maheshwarkar, M., \& Sohani, N. (2013). Combined AHP-TOPSIS based approach for the evaluation of knowledge sharing capabilities of supply chain partners. Management Science and Engineering, 7, 2732.

Mangiarotti, G., \& Mention, A.-L. (2015). Investigating firm-level effects of knowledge management strategies on innovation performance. International Journal of Innovation Management, 19, 1550012.

Manuti, A., Pastore, S., Scardigno, A. F., Giancaspro, M. L., \& Morciano, D. (2015). Formal and informal learning in the workplace: A research review. International Journal of Training and Development, 19, $1-17$.

Marcoulides, G. A., Chin, W. W., \& Saunders, C. (2009). A critical look at partial least squares modeling. MIS Quarterly, 33, 171-175.

Marcoulides, G. A., \& Saunders, C. (2006). Editor's comments: PLS: a silver bullet? MIS Quarterly, 30, iiiix.

Martin, L. M., \& Matlay, H. (2003). Innovative use of the Internet in established small firms: The impact of knowledge management and organisational learning in accessing new opportunities. Qualitative Market Research: An International Journal, 6, 18-26.

Martínez-Ros, E., \& Orfila-Sintes, F. (2012). Training plans, manager's characteristics and innovation in the accommodation industry. International Journal of Hospitality Management, 31, 686-694. doi:10.1016/j.ijhm.2011.09.004

McAdam, R., Reid, R. S., \& Gibson, D. A. (2004). Innovation and organisational size in Irish SMEs: An empirical study. International Journal of Innovation Management, 8, 147-165.

McIver, D., Lengnick-Hall, C. A., Lengnick-Hall, M. L., \& Ramachandran, I. (2013). Understanding work and knowledge management from a knowledge-in-practice perspective. Academy of Management Review, 38, 597-620.

Michailova, S., McCarthy, D. J., Puffer, S. M., May, R. C., \& Stewart Jr, W. H. (2013). Building theory with BRICs: Russia's contribution to knowledge sharing theory. Critical Perspectives on International Business, 9, 147-172.

Michie, J., \& Sheehan, M. (2005). Business strategy, human resources, labour market flexibility and competitive advantage. The International Journal of Human Resource Management, 16, 445-464.

Mintzberg, H. (2011). From management development to organization development with Impact. $O d$ Practitioner, 43, 25-29.

Minzberg, H., \& Quinn, J. B. (1991). The strategy process. Englewood Cliffs, NJ: Prentice-Hall.

Moffett, S., \& Hinds, A. (2010). Assessing the impact of KM on organisational practice: Applying the MeCTIP model to UK organizations. Electronic Journal of Knowledge Management (EJKM), 8, 103118.

Morgan, R. E., \& Berthon, P. (2008). Market orientation, generative learning, innovation strategy and business performance inter-relationships in bioscience firms. Journal of Management Studies, 45, 1329-1353. doi:10.1111/j.1467-6486.2008.00778.x

Mosconi, E., \& Roy, M. C. (2013). Making links between knowledge management and organizational performance. International Business Research, 6. doi:10.5539/ibr.v6n9p68 
Mudambi, R. (2008). Location, control and innovation in knowledge-intensive industries. Journal of economic Geography, 8, 699-725.

Naranjo-Valencia, J. C., Jiménez-Jiménez, D., \& Sanz-Valle, R. (2011). Innovation or imitation? The role of organizational culture. Management Decision, 49, 55-72. doi:10.1108/00251741111094437

Nawaz, M. S., Hassan, M., \& Shaukat, S. (2014). Impact of knowledge management practices on firm performance: Testing the mediation role of innovation in the manufacturing sector of Pakistan. Pakistan Journal of Commerce and Social Sciences, 8, 99-111.

Nelson, R. R., \& Winter, S. G. (2002). Evolutionary theorizing in economics. Journal of Economic Perspectives, 16, 23-46.

Nonaka, I. (2008). The knowledge-creating company. Cambridge, MA: Harvard Business Review Press.

Nonaka, I., Kodama, M., Hirose, A., \& Kohlbacher, F. (2014). Dynamic fractal organizations for promoting knowledge-based transformation-A new paradigm for organizational theory. European Management Journal, 32, 137-146.

Nonaka, I., \& Nishiguchi, T. (2001). Knowledge and emergence: Social, technical, and evolutionary dimensions of knowledge creation. Oxford, UK: Oxford University Press.

Nonaka, I., \& Takeuchi, H. (1995). The knowledge-creating company: How Japanese companies create the dynamics of innovation. Oxford, UK: Oxford University Press.

Norman, D. A., \& Verganti, R. (2014). Incremental and radical innovation: Design research vs. technology and meaning change. Design Issues, 30, 78-96.

Noruzy, A., Dalfard, V., Azhdari, B., Nazari-Shirkouhi, S., \& Rezazadeh, A. (2013). Relations between transformational leadership, organizational learning, knowledge management, organizational innovation, and organizational performance: An empirical investigation of manufacturing firms. International Journal of Advanced Manufacturing Technology, 64, 1073-1085. doi:10.1007/s00170012-4038-y

Nunnally, J. (1978). Psychometric methods. New York: McGraw-Hill.

Nwachukwu, S. L. S., Vitell, S. J., Gilbert, F. W., \& Barnes, J. H. (1997). Ethics and social responsibility in marketing: An examination of the ethical evaluation of advertising strategies. Journal of Business Research, 39, 107-118.

O'Regan, N., Ghobadian, A., \& Sims, M. (2006). Fast tracking innovation in manufacturing SMEs. Technovation, 26, 251-261. doi:10.1016/j.technovation.2005.01.003

OECD. (2003). Organization for economic cooperation and development. Measurement of knowledge management: Practices measuring knowledge management in the business sector. Paris, France: $\mathrm{OECD} /$ Minister of Industry.

OECD. (2014a, September, 2014). Organisation for economic co-operation and development. Economic studies, Spain: 2014. Retrieved from https://books.google.com.mx/books?id=KIZyBAAAQBAJ

OECD. (2014b). Organisation for economic co-operation and development. Perspectivas de la OCDE sobre ciencia, tecnología e industria 2014 (Version abreviada) Informe Iberoamericano: Informe Iberoamericano. Paris, France: OECD Publishing.

OECD. (2015a). Organisation for economic co-operation and development. Tax policy studies taxation of SMEs in OECD and G20 countries. Paris, France: OECD Publishing.

OECD. (2015b). Organisation for economic co-operation and development. The innovation imperative contributing to productivity, growth and well-being: Contributing to productivity, growth and wellbeing. Paris, France: OECD Publishing.

Oncioiu, I. (2013). Business innovation, development, and advancement in the digital economy. Hershey, PA: IGI Global. 
Pai, F.-Y., \& Chang, H.-F. (2013). The effects of knowledge sharing and absorption on organizational innovation performance-a dynamic capabilities perspective. Interdisciplinary Journal of Information, Knowledge, and Management, 8, 83-97. Retrieved from http://www.informingscience.org/Publications/1904

Palacios-Marqués, D., Soriano, D. R., \& Huarng, K. H. (2015). New information and communication technologies for knowledge management in organizations. In 5th Global Innovation and Knowledge Academy Conference, GIKA 2015, (pp. Valencia, Spain.

Palacios Marqués, D., \& José Garrigós Simón, F. (2006). The effect of knowledge management practices on firm performance. Journal of Knowledge Management, 10, 143-156. doi:10.1108/13673270610670911

Parida, V., Westerberg, M., \& Frishammar, J. (2012). Inbound open innovation activities in high-tech SMEs: The impact on innovation performance. Journal of Small Business Management, 50, 283-309.

Parjanen, S. (2012). Experiencing creativity in the organization: From individual creativity to collective creativity. Interdisciplinary Journal of Information, Knowledge, and Management, 7, 109-128. Retrieved from http://www.informingscience.org/Publications/1580

Peinl, R., \& Maier, R. (2011). SimKnowledge-Analyzing impact of knowledge management measures on team organizations with multi agent-based simulation. Information Systems Frontiers, 13, 621-636.

Peng, D. X., \& Lai, F. (2012). Using partial least squares in operations management research: A practical guideline and summary of past research. Journal of Operations Management, 30, 467-480.

Perrin, A., Vidal, P., \& McGill, J. (2006). Valuing knowledge sharing in Lafarge. Knowledge and Process Management, 13, 26-34.

Pillania, R. K. (2013). Leadership, knowledge management and sustainable growth: A spiritual dimension. Values-Based Management, 3, 57-66.

Podsakoff, P. M., \& Organ, D. W. (1986). Self-reports in organizational research: Problems and prospects. Journal of Management, 12, 531-544.

Poletti, M. J., Engelland, B. T., \& Ling, H. G. (2011). An empirical study of declining lead times: Potential ramifications on the performance of early market entrants. Journal of Marketing Theory and Practice, 19, 27-38.

Porter, M. E. (2011). The competitive advantage of nations, states and regions. National Council of Professors Kuala Lumpur.

Price, D. P., Stoica, M., \& Boncella, R. J. (2013). The relationship between innovation, knowledge, and performance in family and non-family firms: An analysis of SMEs. Journal of Innovation and Entrepreneurship, 2, 1-20.

Prusak, L., \& Matson, E. (2006). Knowledge management and organizational learning: A reader. Oxford, UK: Oxford University Press.

Quinn, D., \& Shapiro, R. Y. (1991). Economic growth strategies: The effects of ideological partisanship on interest rates and business taxation in the United States. American Journal of Political Science, 35, 656-685.

Quinn, J. (2005). The intelligent enterprise a new paradigm. The Academy of Management Executive, 19, $109-121$.

Ragab, M., \& Arisha, A. (2013). Knowledge management and measurement: A critical review. Journal of Knowledge Management, 17, 873-901.

Rahimi, H., Arbabisarjou, A., Allameh, S. M., \& Aghababaei, R. (2011). Relationship between knowledge management process and creativity among faculty members in the University. Interdisciplinary Journal of Information, Knowledge, and Management, 6, 17-33. Retrieved from http://www.informingscience.org/Publications/1360 
Management of Knowledge, Innovation and Performance in SMEs

Ramírez, A. M., Vasauskaite, J., \& Kumpikaitè, V. (2012). Role of knowledge management within innovation and performance. Economics and Management, 17, 381-389. doi:10.5755/j01.em.17.1.2293

Reio, T. G. (2010). The threat of common method variance bias to theory building. Human Resource Development Review, 9, 405-411.

Remus, S. (2012). The intellectual capital in knowledge-based society and economy. The Annals of the University of Oradea. Journal Economic Sciences, 21, 1066-1074.

Renzl, B. (2008). Trust in management and knowledge sharing: The mediating effects of fear and knowledge documentation. Omega, 36, 206-220.

Riege, A. (2005). Three-dozen knowledge-sharing barriers managers must consider. Journal of Knowledge Management, 9, 18-35.

Rigdon, E. E. (2012). Rethinking partial least squares path modeling: In praise of simple methods. Long Range Planning, 45, 341-358.

Ringle, C. M., Sarstedt, M., \& Straub, D. (2012). A critical look at the use of PLS-SEM in MIS Quarterly. MIS Quarterly (MISQ), 36, iii-xiv.

Ringle, C. M., Wende, S., \& Becker, J.-M. (2014). SmartPLS 3. Hamburg: SmartPLS.

Robbins, S. P., DeCenzo, D. A., \& Gao, J. (2007). Fundamentals of management. Upper Saddle River, NJ: Pearson Prentice Hall.

Roberts, P., Priest, H., \& Traynor, M. (2006). Reliability and validity in research. Nursing Standard, 20, 41.

Robertson, P. L., \& Jacobson, D. (2011). Knowledge transfer and technology diffusion. Cheltenham, UK: Edward Elgar Publishing Limited.

Roos, G., \& Roos, J. (1997). Measuring your company's intellectual performance. Long Range Planning, $30,413-426$.

Roxas, B., Battisti, M., \& Deakins, D. (2014). Learning, innovation and firm performance: Knowledge management in small firms. Knowledge Management Research \& Practice, 12, 443-453.

Rüdiger, K., Peris-Ortiz, M., \& Blanco-González, A. (2013). Entrepreneurship, innovation and economic crisis: Lessons for research, policy and practice. Cham, Switzerland: Springer International Publishing.

Ruggles, R., \& Little, R. (1997). Knowledge management and innovation: An initial exploration. Center for Business Innovationism.

Sain, S., \& Wilde, S. (2014). Soft skills within customer knowledge management and their impact on customer focus Customer knowledge management (pp. 57-85). Switzerland: Springer.

Šajeva, S., \& Jucevičius, R. (2008). Linking knowledge management and organizational innovativeness. Social Sciences (1392-0758), 59, 50-57.

Sankar, K., \& Bouchard, S. A. (2009). Enterprise web 2.0 fundamentals. Indianapolis, IN: Cisco Press.

Sarstedt, M., Ringle, C. M., Henseler, J., \& Hair, J. F. (2014). On the emancipation of PLS-SEM: A commentary on Rigdon (2012). Long Range Planning, 47, 154-160.

Scarbrough, H., \& Swan, J. (2001). Explaining the diffusion of knowledge management: The role of fashion. British Journal of Management, 12, 3-12.

Schaper, M. T., Dana, L. P., Anderson, R. B., \& Moroz, P. W. (2009). Distribution of firms by size: Observations and evidence from selected countries. International Journal of Entrepreneurship and Innovation Management, 10, 88-96.

Schatten, M. (2013). Knowledge management in semantic social networks. Computational and Mathematical Organization Theory, 19, 538-568.

Schein, E. H. (1990). Organizational culture: American Psychological Association. 
Schein, E. H. (2010). Organizational culture and leadership. Chichester, UK: John Wiley \& Sons.

Schiuma, G., Andreeva, T., \& Kianto, A. (2012). Does knowledge management really matter? Linking knowledge management practices, competitiveness and economic performance. Journal of Knowledge Management, 16, 617-636. doi:10.1108/13673271211246185

Schmitt, U. (2015). Putting personal knowledge management under the macroscope of informing science. Informing Science: the International Journal of an Emerging Transdiscipline, 18, 145-176. Retrieved from http://www.informingscience.org/Publications/2161

Senaji, T., \& Nyaboga, A. B. (2011). Knowledge management process capability: Operations strategy perspective. International Journal of Management \& Information Systems (IJMIS), 15, 147-158.

Shafritz, J., Ott, J., \& Jang, Y. (2015). Classics of organization theory. Mason, OH: Cengage Learning.

Shih, K.-H., Chang, C.-J., \& Lin, B. (2010). Assessing knowledge creation and intellectual capital in banking industry. Journal of Intellectual Capital, 11, 74-89.

Sigler, K. J. (2011). CEO Compensation and company performance. Business and Economic Journal, 2011, 1-8.

Simatupang, T. M., \& White, A. J. (2010). A policy resolution model for knowledge acquisition in quality management. Total Quality Management, 9, 767-779. doi:10.1080/0954412988235

Škerlavaj, M., Song, J. H., \& Lee, Y. (2010). Organizational learning culture, innovative culture and innovations in South Korean firms. Expert Systems with Applications, 37, 6390-6403. doi:10.1016/j.eswa.2010.02.080

Soliman, F. (2015). From knowledge management to learning organisation to innovation: The way ahead! Newcastle upon Tyne: Cambridge Scholars Publishing.

Sople, V. V. (2014). Managing intellectual property: The strategic imperative. New Delhi, India: PHI Learning Pvt. Ltd.

Sparrow, P. (2010). Handbook of international human resource management: Integrating people, process, and context. Chichester, UK: John Wiley \& Sons.

Sultan, N. (2013). Knowledge management in the age of cloud computing and Web 2.0: Experiencing the power of disruptive innovations. International Journal of Information Management, 33, 160-165.

Swan, J., Newell, S., Scarbrough, H., \& Hislop, D. (1999). Knowledge management and innovation: Networks and networking. Journal of Knowledge Management, 3, 262-275. doi:10.1108/13673279910304014

Swan, J., Scarbrough, H., \& Robertson, M. (2002). The construction of 'communities of practice' in the management of innovation. Management Learning, 33, 477-496. doi:10.1177/1350507602334005

Syed, N., \& Lin, X. (2013). Relationship between human resource management practices and enterprise innovation: Mediating role of creative culture. In Proceedings of the 2013 International Conference on Information, Business and Education Technology (ICIBET 2013), (pp.

Tanriverdi, H. (2005). Information technology relatedness, knowledge management capability, and performance of multibusiness firms. MIS Quarterly, 29, 311-334.

Tanriverdi, H. (2006). Performance effects of information technology synergies in multibusiness firms. MIS Quarterly, 30, 57-77.

Teece, D. J. (2007). Explicating dynamic capabilities: The nature and microfoundations of (sustainable) enterprise performance. Strategic Management Journal, 28, 1319-1350.

Teece, D. J., Pisano, G., \& Shuen, A. (2009). Dynamic capabilities and strategic management. In M. H. Zack (Ed.), Knowledge and strategy (pp. 77-116). Woburn, MA: Butterworth-Heinemann. 
Theriou, N., Maditinos, D., \& Theriou, G. (2010). Knowledge management enabler factors and firm performance: An empirical research of the greek medium and large firms. In International Conference on Applied Business \& Economics ICABE.

Tseng, F.-C., \& Fan, Y.-J. (2011). Exploring the influence of organizational ethical climate on knowledge management. Journal of Business Ethics, 101, 325-342. doi:10.1007/s10551-010-0725-5

Tunc Bozbura, F. (2004). Measurement and application of intellectual capital in Turkey. The Learning Organization, 11, 357-367.

Tunc Bozbura, F. (2007). Knowledge management practices in Turkish SMEs. Journal of Enterprise Information Management, 20, 209-221.

Uma Mageswari, S. D., Sivasubramanian, C., \& Srikantha Dath, T. N. (2015). Knowledge management enablers, processes and innovation in small manufacturing firms: A structural equation modeling approach. IUP Journal of Knowledge Management, 13, 33.

United-Nations. (2015). University international human dimensions programme, United Nations Environment Programme. Inclusive wealth report 2014. Cambridge, MA: Cambridge University Press.

Urbach, N., \& Ahlemann, F. (2010). Structural equation modeling in information systems research using partial least squares. Journal of Information Technology Theory and Application, 11, 5-40.

Vaccaro, A., Parente, R., \& Veloso, F. M. (2010). Knowledge management tools, inter-organizational relationships, innovation and firm performance. Technological Forecasting and Social Change, 77, 1076-1089. doi:10.1016/j.techfore.2010.02.006

Valdez, L. J., \& Maldonado, G. G. (2015). [Knowledge management and its influence on the Innovation of SMEs (XVIII Congreso AECA: Asociación Española de Contabilidad y Administración de Empresas), Cartagena España.].

Van Hemert, P., Nijkamp, P., \& Masurel, E. (2013). From innovation to commercialization through networks and agglomerations: Analysis of sources of innovation, innovation capabilities and performance of Dutch SMEs. The Annals of Regional Science, 50, 425-452.

Vandenberg, R. J., \& Lance, C. E. (2000). A review and synthesis of the measurement invariance literature: Suggestions, practices, and recommendations for organizational research. Organizational Research Methods, 3, 4-70.

Velu, C. (2015). Knowledge management capabilities of lead firms in innovation ecosystems. AMS Review, $5,123-141$.

Von Krogh, G., Takeuchi, H., Kase, K., \& González, C. (2013). Towards organizational knowledge: The pioneering work of Ikujiro Nonaka. Houndmills, Basingstoke, Hampshire: Palgrave Macmillan.

Wang, J., \& Wang, X. (2012). Structural equation modeling: Applications using Mplus. Chichester, UK: John Wiley \& Sons.

Wang, S., \& Noe, R. A. (2010). Knowledge sharing: A review and directions for future research. Human Resource Management Review, 20, 115-131.

Wang, Y., Chen, Y., \& Benitez-Amado, J. (2015). How information technology influences environmental performance: Empirical evidence from China. International Journal of Information Management, 35, 160-170.

Wetzels, M., Odekerken-Schröder, G., \& Van Oppen, C. (2009). Using PLS path modeling for assessing hierarchical construct models: Guidelines and empirical illustration. MIS Quarterly, 33, 177-195.

Wiig, K. M. (2002). Knowledge management has many facets. Arlington, TX: Knowledge Research Institute, Inc.

Winter, S. G. (2005). Developing evolutionary theory for economics and management. Great minds in management, 209-546. 
Yang, J. (2010). The knowledge management strategy and its effect on firm performance: A contingency analysis. International Journal of Production Economics, 125, 215-223.

Yeşil, S., \& Hırlak, B. (2013). An empirical investigation into the influence of knowledge sharing barriers on knowledge sharing and individual innovation behaviour. International Journal of Knowledge Management (IJKM), 9, 38-61.

Yew Wong, K. (2005). Critical success factors for implementing knowledge management in small and medium enterprises. Industrial Management \& Data Systems, 105, 261-279. doi:10.1108/02635570510590101

Yew Wong, K., \& Aspinwall, E. (2005). An empirical study of the important factors for knowledgemanagement adoption in the SME sector. Journal of Knowledge Management, 9, 64-82.

Youndt, M. A., Subramaniam, M., \& Snell, S. A. (2004). Intellectual capital profiles: An examination of investments and returns. Journal of Management Studies, 41, 335-361.

Yu, C., Yu-Fang, T., \& Yu-Cheh, C. (2013). Knowledge sharing, organizational climate, and innovative behavior: A cross-level analysis of effects. Social Behavior and Personality: An International Journal, 41, 143-156. doi:10.2224/sbp.2013.41.1.143

Yu, Y., Dong, X.-Y., Shen, K. N., Khalifa, M., \& Hao, J.-X. (2013). Strategies, technologies, and organizational learning for developing organizational innovativeness in emerging economies. Journal of Business Research, 66, 2507-2514. doi:10.1016/j.jbusres.2013.05.042

Yüksel, H. (2008). An empirical evaluation of cleaner production practices in Turkey. Journal of Cleaner Production, 16, S50-S57.

Zack, M., McKeen, J., \& Singh, S. (2009). Knowledge management and organizational performance: An exploratory analysis. Journal of Knowledge Management, 13, 392-409.

Zack, M. H., \& Singh, S. (2010). A knowledge-based view of outsourcing. International Journal of Strategic Change Management, 2, 32-53.

Zahra, S. A., \& George, G. (2002). Absorptive capacity: A review, reconceptualization, and extension. The Academy of Management Review, 27, 185. doi:10.2307/4134351

Zahra, S. A., \& Hayton, J. C. (2008). The effect of international venturing on firm performance: The moderating influence of absorptive capacity. Journal of Business Venturing, 23, 195-220.

Zahra, S. A., Ireland, R. D., \& Hitt, M. A. (2000). International expansion by new venture firms: International diversity, mode of market entry, technological learning, and performance. Academy of Management Journal, 43, 925-950.

Zeng, S. X., Xie, X. M., \& Tam, C. M. (2010). Relationship between cooperation networks and innovation performance of SMEs. Technovation, 30, 181-194. doi:10.1016/j.technovation.2009.08.003

Zheng, W., Yang, B., \& McLean, G. N. (2010). Linking organizational culture, structure, strategy, and organizational effectiveness: Mediating role of knowledge management. Journal of Business Research, $63,763-771$.

Zhu, Y., Wittmann, X., \& Peng, M. W. (2011). Institution-based barriers to innovation in SMEs in China. Asia Pacific Journal of Management, 29, 1131-1142. doi:10.1007/s10490-011-9263-7 


\section{Appendix}

\section{Survey}

\section{Sponsor by:}

Observatorio Económico

de la Pyme

CIF:

ID

\section{Address: St. /}

\begin{tabular}{llll}
\hline$N_{\text {Locality_ }}$ & & & \\
Province & ZIP & CODE \\
\hline
\end{tabular}

1. Indicate the values of the following variables, as well as the trend for 2010:

\begin{tabular}{|l|c|c|c|c|c|}
\hline & \multirow{2}{*}{2008} & \multirow{2}{*}{$\mathbf{2 0 0 9}$} & \multicolumn{3}{|c|}{ Trend 2010 } \\
\cline { 4 - 6 } & & Increase & The same & Decrease \\
\hline The operating income (Euro) & & & $\square 1$ & $\square 2$ & $\square 3$ \\
\hline $\mathrm{N}^{\mathrm{o}}$ middle of employees & & & $\square 1$ & $\square 2$ & $\square 3$ \\
\hline
\end{tabular}

2. How many years have your company been running? years.

\section{KNOWLEDGE MANAGEMENT}

Training: 1= Strongly Disagree (SD), 2= Disagree (D), 3= Neutral (N), 4= Agree (A), 5= Strongly Agree (SA)

\begin{tabular}{|c|c|c|c|c|c|}
\hline 3. Please indicate if your company... & SD & $\mathrm{D}$ & $\mathrm{N}$ & A & SA \\
\hline $\begin{array}{l}\text { KMF1. Constantly provides its workers and employees a formal training related to } \\
\text { knowledge management. }\end{array}$ & 1 & 2 & 3 & 4 & 5 \\
\hline $\begin{array}{l}\text { KMF2. Constantly provides its workers and employees' informal training related to } \\
\text { knowledge management. }\end{array}$ & 1 & 2 & 3 & 4 & 5 \\
\hline KMF3. Consistently used formal consulting practices to their work and employees. & 1 & 2 & 3 & 4 & 5 \\
\hline
\end{tabular}

Policies and strategies: $1=$ Strongly Disagree (SD), 2= Disagree (D), 3= Neutral (N), 4= Agree (A), 5= Strongly Agree (SA)

\begin{tabular}{|c|c|c|c|c|c|}
\hline 4. Please indicate if your company... & $\overline{\mathrm{SD}}$ & $\overline{\mathrm{D}}$ & $\mathrm{N}$ & $\overline{\mathrm{A}}$ & $\overline{\mathrm{SA}}$ \\
\hline KMP1. Constantly implements new ideas & 1 & 2 & 3 & 4 & 5 \\
\hline KMP2. Constantly supports the development of ideas & 1 & 2 & 3 & 4 & 5 \\
\hline KMP3. Has quick access to information that requires & 1 & 2 & 3 & 4 & 5 \\
\hline
\end{tabular}




\begin{tabular}{|c|c|c|c|c|c|}
\hline KMP4. Has procedure established to support innovation & 1 & 2 & 3 & 4 & 5 \\
\hline KMP5. Has a bureaucratic system & 1 & 2 & 3 & 4 & 5 \\
\hline KMP6. Has quickly access from databases & 1 & 2 & 3 & 4 & 5 \\
\hline KMP7. Has access to the information required without any limitation & 1 & 2 & 3 & 4 & 5 \\
\hline
\end{tabular}

Acquisition of knowledge: (1= Strongly Disagree (SD), 2= Disagree (D), 3= Neutral (N), 4= Agree (A), $5=$ Strongly Agree (SA)

\begin{tabular}{|c|c|c|c|c|c|}
\hline 5. Please indicate if your company... & SD & $\mathrm{D}$ & $\mathrm{N}$ & A & SA \\
\hline $\begin{array}{l}\text { KMA1. Uses constantly to their own advantage the knowledge gained from other } \\
\text { industrial sources. }\end{array}$ & 1 & 2 & 3 & 4 & 5 \\
\hline $\begin{array}{l}\text { KMA2. Uses constantly to their own advantage the knowledge gained from public } \\
\text { institutions and research centres. }\end{array}$ & 1 & 2 & 3 & 4 & 5 \\
\hline $\begin{array}{l}\text { KMA3. Constantly dedicated resources to obtaining knowledge of external agen- } \\
\text { cies. }\end{array}$ & 1 & 2 & 3 & 4 & 5 \\
\hline KMA4. Constantly used the Internet to obtain the external knowledge required. & 1 & 2 & 3 & 4 & 5 \\
\hline $\begin{array}{l}\text { KMA5. Constantly encouraged his workers and employees to participate in team } \\
\text { projects with external experts. }\end{array}$ & 1 & 2 & 3 & 4 & 5 \\
\hline
\end{tabular}

Organizational culture: $1=$ Strongly Disagree (SD), 2= Disagree (D), 3= Neutral (N), 4= Agree (A), 5= Strongly Agree (SA)

\begin{tabular}{|c|c|c|c|c|c|}
\hline 6. Please indicate if your company... & SD & $\mathrm{D}$ & $\mathrm{N}$ & A & SA \\
\hline $\begin{array}{l}\text { KMC1. Constantly encourages its managers and workers to transfer their experi- } \\
\text { ences and knowledge to new workers and employees. }\end{array}$ & 1 & 2 & 3 & 4 & 5 \\
\hline $\begin{array}{l}\text { KMC2. It has well established a system of values and cultural promotion among its } \\
\text { workers and employees. }\end{array}$ & 1 & 2 & 3 & 4 & 5 \\
\hline $\begin{array}{l}\text { KMC3. Constantly motivates employees and employees to work as a team in the } \\
\text { different activities carried out. }\end{array}$ & 1 & 2 & 3 & 4 & 5 \\
\hline $\begin{array}{l}\text { KMC4. Constantly encourages its managers and workers to transfer their experi- } \\
\text { ences and knowledge to new workers and employees. }\end{array}$ & 1 & 2 & 3 & 4 & 5 \\
\hline
\end{tabular}

\section{INNOVATIVE ACTIVITY}

Innovation:1= Unimportant (U), 2= Less important (LI), 3= Neutral (N), 4= Important (I), 5= Very important(VI)

\begin{tabular}{|l|l|l|l|l|l|l|l|}
\hline $\begin{array}{l}\text { Has it made a change or improvement in its products, processes or } \\
\text { systems of management in the last year? If yes, indicate the degree } \\
\text { of importance of these changes for your company } \\
(0)\end{array}$ & $\begin{array}{l}\text { Yes } \\
(1)\end{array}$ & U & LI & N & VI \\
\hline $\begin{array}{l}\text { Innovation in products and services } \\
\text { INNP1. Changes or improvements in existing products/services }\end{array}$ & & & 1 & 2 & 3 & 4 & 5 \\
\hline INNP2. Marketing new products/services & & & 1 & 2 & 3 & 4 & 5 \\
\hline $\begin{array}{l}\text { Innovation in processes } \\
\text { INNP3. Changes or improvements in the processes of produc- } \\
\text { tion/services }\end{array}$ & & & 2 & 3 & 4 & 5 \\
\hline \begin{tabular}{l} 
INNP4. Acquisition of new equipment goods \\
\hline
\end{tabular}
\end{tabular}


Performance: 1 = Very Unfavorable (VU), 2= Unfavorable (U), $3=$ Neutral $(\mathrm{N}), 4=$ Favorable $(\mathrm{F}), 5=$ Very Favorable (VF)

\begin{tabular}{|l|c|c|c|c|c|}
\hline $\begin{array}{l}\text { 8. Indicate what has been the evolution of the following aspects in your } \\
\text { company in the past two years. }\end{array}$ & VU & $\mathrm{U}$ & $\mathrm{F}$ & $\mathrm{VF}$ \\
\hline RENR1. Increase of market share & 1 & 2 & 3 & 4 & 5 \\
\hline RENR2. Increase of profitability & 1 & 2 & 3 & 4 & 5 \\
\hline RENR3. Increase in productivity & 1 & 2 & 3 & 4 & 5 \\
\hline
\end{tabular}

\section{Biographies}

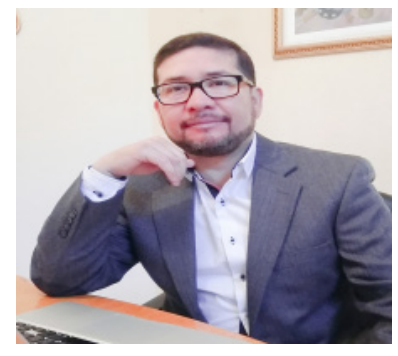

Luis Enrique Valdez-Juárez is a researcher professor, category A of Instituto Tecnológico de Sonora in México, with a Masters in Business Administration. It is also a business consultant in SMEs. In the field of research he is in the area of Management of Human Capital and the SME Corporate Social Responsibility. He is currently a PhD student in Management and Business Management of the Polytechnic University of Cartagena (UPCT), in Murcia Spain. Responsible for coordinating Mexico Northwest International Foundation Research Network for Strategic Development of SMEs (FAEDPYME).

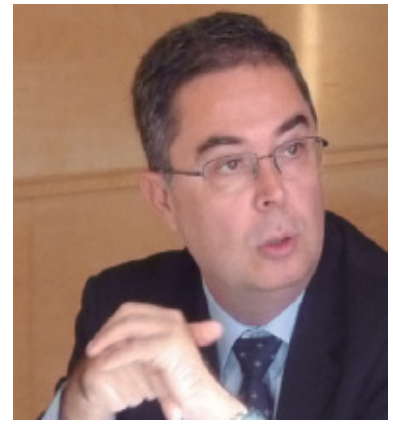

Domingo García-Pérez de Lema is Professor of Financial Economics and Accounting at the Polytechnic University of Cartagena (UPCT), Spain. President of Finance and Business Valuation Commission (AECA). Director of the Economic Observatory of SMEs in the Region of Murcia, Spain. Co-Director of the Foundation for Strategic Development of SMEs (FAEDPYME). His research covers different field of SME such as: corporate culture, innovation, family business and prediction of business failure. He is responsible for Business Valuation in Entrepreneurship Center of UPCT.

https://www.researchgate.net/profile/Domingo_Garcia-Perez-de-Lema https://scholar.google.es/citations?user=RM0u0yAAAAAJ

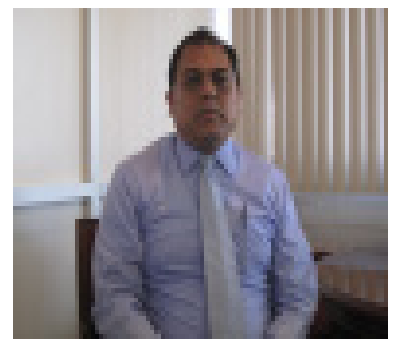

Gonzalo Maldonado-Guzmán obtained his Ph.D. in Marketing at the University of Valencia in Spain. Dr. Guzmán is currently coordinator of the SME Observatory at the Autonomous University of Aguascalientes (UAA), as well as Lecturer in the $\mathrm{PhD}$ in Business Administration, Master in Business Administration and undergraduate programs. His research areas of interest are Marketing Mix, Corporate Social Responsibility, SMEs Innovation, Information Technology, and Intellectual Property in SMEs Knowledge Management in SMES. Dr. Gonzalo has been leader of various research projects in Innovation and Knowledge Management in SMEs in the region of Aguascalientes, Mexico, and projects developed along with Universities of Murcia, Cantabria and University of Cartagena, Spain. 